Santos D.S., Mansur K.L., Seoane J.C.S., Mucivuna V.C., Reynard E. (2020). Methodological proposal for the inventory and assessment of geomorphosites: An integrated approach focused on territorial management and geoconservation. Environmental Management. https://doi.org/10.1007/s00267-020$\underline{01324-2}$ (post-print)

\title{
Methodological Proposal for the Inventory and Assessment of Geomorphosites: An Integrated Approach Focused on Territorial Management and Geoconservation
}

\author{
Daniel S. Santos ${ }^{1}$; Kátia L. Mansur ${ }^{1}$; José C. S. Seoane ${ }^{1}$; Vanessa C. Mucivuna²; \\ Emmanuel Reynard ${ }^{3}$
}

1 Post-Graduation Program in Geology - Federal University of Rio de Janeiro

2 Institute of Geosciences - University of São Paulo

3 Institute of Geography and Sustainability and Interdisciplinary Center for Mountain Research - University of Lausanne

\author{
*Daniel S. Santos \\ danielsouza@id.uff.br
}

\begin{abstract}
Geoconservation has been growing in importance within the environmental management context. The conservation of geological heritage is being more and more recognised as an essential issue in nature conservation. Inventories of geosites are considered basic steps in geoconservation strategies and constitute a tool to support management considering the sites' values, use potential and risks of degradation. There are dozens of proposed methods to create inventories and to perform qualitative and quantitative evaluations of the sites and there are still discussions concerning the issues of how to select and evaluate sites and provide management guidelines. Geomorphosites are geosites with geomorphological nature and it is a category that presents some peculiarities highlighted in the literature. This work aimed at proposing a method for inventorying and assessing geomorphosites designed for territorial management focused on the use potential of the sites, divided into scientific, educational and geotouristic uses, the promotion conditions and the risks of degradation. The method was applied to the southeast coast of Rio de Janeiro State, Brazil, which has a high geomorphological diversity. The result was the creation of an inventory of geomorphosites in which all sites were described and quantitatively assessed, creating a product that can be easily applied in the management of the sites. The objective of this work was to contribute to the methodological discussions and to strengthen the insertion of geoconservation on territorial management.
\end{abstract}

Keywords: Geomorphosites, Inventory, Methodology, Geoconservation 


\section{INTRODUCTION}

The scientific interest in geoheritage has been growing significantly in the last decades and many initiatives of protection and promotion are being carried out all around the world (Reynard and Brilha 2018). The emergence of geoconservation as a new geoscientific domain concerned with the conservation, management and sustainable use of geodiversity elements, although recent, is becoming an essential topic within public policies, scientific research, nature conservation etc. (Brocx and Semeniuk 2007; Henriques et al. 2011; Brilha 2017).

Geodiversity, as defined in Gray (2013) corresponds to the "natural range (diversity) of geological (rocks, minerals, fossils), geomorphological (landforms, topography, physical processes), soil and hydrological features. It includes their assemblages, structures, systems and contributions to landscape". The importance of geodiversity can be seen in different contexts and perspectives, such as ecosystem services (e.g Gordon et al. 2012; Gray 2013; Gray et al. 2013), biodiversity conservation (e.g Parks and Mulligan 2010; Comer et al. 2015; Hjort et al. 2015) and territorial management (e.g Pereira et al. 2013; Pellitero et al. 2014; Santos et al. 2017). Therefore, since the physical environment is the basis for the development of human societies and biodiversity, it is clear that geodiversity should occupy a more central role in environmental management issues (Brilha et al. 2018).

Ecosystem services are "the conditions and processes through which natural ecosystems, and the species that make them up, sustain and fulfil human life" (Daily 1997). The Millennium Ecosystem Assessment (2005) defined four categories for ecosystem services: regulating, supporting, provisioning and cultural. Within this context, Gray (2011) highlighted the values derived from the abiotic environment (geodiversity), referring to them as geosystem services. Gray et al. (2013) "updated" the term to abiotic ecosystem services and included the knowledge services within the cultural services. This new category concerns the understanding of Earth's history, history of research, environmental monitoring and forecasting, geoforensics, education and employment. Gordon et al. (2012) highlighted that geodiversity also provides the knowledge to help society to adapt to new climate conditions and to mitigate the effects of natural hazards, enhancing the importance of the knowledge services and geodiversity as a whole in territorial management.

Taking into account the relevance of knowledge services, two other concepts must be emphasised: geoheritage and geosites. According to Reynard (2009), there are two approaches to define geosites, a broader one and a more restrictive one. Authors such as Panizza (2001) presented a broad definition in which geosites refer to in situ occurrences presenting a specific value (scientific, ecological, economic, cultural or aesthetic) due to human perception or exploitation. A more restrictive definition was proposed by Grandgirard (1999), in which geosites are geological objects presenting a particular relevance for the understanding of Earth's history. Reynard $(2005,2009)$ proposed to distinguish a central (scientific) value and several additional values for geoheritage sites. According to Brilha (2016), geoheritage refers to occurrences with high scientific value. These occurrences may be in-situ or ex-situ (e.g minerals, rocks or fossils in a museum collection). The in-situ occurrences should be called geosites if they have a high 
geoscientific importance and geodiversity sites if their geoscientific importance is not so high but they present other interests (see Brilha 2016 for other related concepts). Therefore, the concepts of geoheritage and geosites are directly associated with the knowledge services, being part of the culture services category.

There are still discussions in the geoconservation community about the proposal of Brilha (2016). However, independent of the approach (broad or restrictive), geosites are valued occurrences of geodiversity elements that should be managed in order to be protected from degradation or destruction. To answer the question on how should geosites be selected for protection, inventories are being carried out in many countries. Most of the initiatives were based in Europe (e.g Wimbledon and Smith-Meyer 2012), but national or regional inventories are now being developed in many other parts of the world, such as Brazil (e.g Santos et al. 2016; Garcia et al. 2018; Ferreira et al. 2019), Ethiopia (e.g Megerssa et al. 2019), Morocco (e.g Beraaouz et al. 2019), Egypt (e.g Khalaf et al. 2019), Mexico (e.g Silva-García et al. 2019), Vietnam (e.g Phuong et al. 2017) and others.

An inventory must be well-structured and based on a reliable methodology, otherwise relevant geosites may be undervalued or even unidentified. According to Lima et al. (2010), the objective of the inventory must be clear and, in order to define this objective, four issues must be considered: the topic (i.e subject or theme); the value (e.g scientific, educational, touristic etc.); the scale (i.e the geographical area covered by the inventory); and the use (i.e the purpose of the inventory). The criteria must be transparent and in accordance with the assessed values, allowing an unbiased selection, and the subjectivity degree must be as low as possible (Brilha 2018). Concerning subjectivity, Bruschi et al. (2011) applied a statistical approach to identify the most significant criteria and proposed a parametric method based on objective and clearly defined criteria. An interesting contribution of the work of Bruschi et al. (2011) was to show that a higher number of criteria does not imply a better quality of the assessment.

The benefits of geodiversity elements for society are usually associated to mineral resources that are exploited. However, there is a growing understanding that the benefits go way beyond quarrying and mining activities and many other values and uses of geodiversity are being recognised. Brilha (2018) highlighted three ways in which geodiversity elements are used other than the exploitation of mineral resources: scientific, educational and touristic uses. The use of geosites to continue evolving geoscientific knowledge is essential to ensure the development of human societies. Educational and scientific uses are related, since an important use of geosites is preparing new generations of geoscientists. Additionally, the educational use is also important for schools and science communication. Finally, many geodiversity elements may be used for tourism and leisure, which highlights the possibility of sustainable economic development.

The scientific value is usually addressed as the main/central value (e.g Reynard 2005, 2009; Coratza and Giusti 2005; Pereira and Pereira 2010; Brilha 2016; Reynard et al. 2016), while other values (ecological, cultural, educational etc.) are treated as additional values. The method proposed by Coratza and Giusti (2005), focused on the assessment of the scientific value, emphasised its importance in contexts such as territorial planning, environmental impact assessment and protection of the natural heritage. They also highlighted that the additional values, even when not directly related 
to geoscientific aspects, may enhance the scientific value. Other proposals recognised the importance of other values in the assessment of the scientific, such as Bollati et al. (2015), who included the ecological value or Panizza and Piacente (2005), who integrated the cultural relevance into the scientific value. Zouros (2007) assessed both the educational and the scientific values together. Therefore, even when treated separately, the additional values may be directly associated with the scientific value.

The educational use is important both in formal education and in informal activities, such as science communication. The method presented by Bollati et al. (2012) is focused on educational purposes, which are important due to the fact that processes modifying the landscape affect and are affected by human activities, so the knowledge about this interaction should be spread in the society as a whole. A very interesting example concerning this issue was presented by Coratza and De Waele (2012), who focused on natural hazards and highlighted that making it understandable to the wider public may be an effective way to reduce losses. Another research with high educational potential was presented by Clivaz and Reynard (2018), who made an approach about "invisible geomorphosites", which are geomorphological sites that are no longer visible today due to human activities. By using these sites for educational purposes, it is possible to raise awareness on how human activities can alter landscapes.

Promoting tourism activities is often the main goal of geosites' inventories (Mucivuna et al. 2019). Geotourism is a new and specific form of tourism focused on geology and landscapes (Newsome and Dowling 2010), with the aim to provide geoscientific information to visitors and contribute to the conservation of geodiversity through appreciation and learning about Earth's history (Hose 2012; Dowling 2013). The importance of geotourism for the socio-economic development of local communities was highlighted by Farsani et al. (2011), who focused their analysis in rural areas. However, works such as the one presented by Pica et al. (2016) show that even urbanised areas may benefit from the development of geotourism. A method for assessing the tourist value of geosites is presented by Pralong (2005), who considered four values/parameters in the assessment: scenic, scientific, cultural and economic. This proposal shows how the scientific value can be relevant for the development of economic and sustainable activities.

Systematic inventories are the basis of geoconservation strategies (Henriques et al. 2011; Brilha 2016) and the absence of inventories or the inadequate management of geoheritage may lead to damage or even total destruction of geosites (Lima et al. 2010). Therefore, inventories usually include the assessment of risks of degradation, which is essential for the correct management of the geosites. Concerning this subject, the work of García-Ortiz et al. (2014) must be highlighted for being dedicated to the assessment of risks of degradation. The authors identified a lack of standardised terminology and method and proposed a method based on the concepts of sensitivity, fragility and vulnerability (anthropic and natural). This is an interesting approach for presenting the risks of degradation related to the intrinsic characteristics of the geosites and external factors that may also impose threats, including issues related to the public use of the sites.

Most of the methodological proposals for creating inventories include a quantitative step, when scores are given to evaluate the values of the geosites (e.g Bruschi 
and Cendrero 2005; Coratza and Giusti 2005; Zouros 2007; Lima et al. 2010; Pereira and Pereira 2010; Bollati et al. 2013; Brilha 2016; Reynard et al. 2016). Brilha (2016) stated that the quantitative assessment is only necessary for inventories in large territories. For small areas, this step is not required, since the characterisation and qualitative assessment is enough to support geoconservation strategies. The quantitative assessment aims to reduce subjectivity and helps decision-making by managers, especially when dealing with dozens or even hundreds of geosites. The quantitative assessment is done by the selection of criteria and the attribution of scores to each of them.

Among all categories of geosites, geomorphosites are those that have geomorphological nature (Panizza 2001; Reynard et al. 2009). Many methods for inventorying and assessing geoheritage are specifically focused on geomorphosites (e.g Bruschi and Cendrero 2005; Coratza and Giusti 2005; Pralong 2005; Serrano and González-Trueba 2005; Zouros 2007; Pereira et al. 2007; Bollati et al. 2013; Comănescu et al. 2012; Kubaliková 2012; Reynard et al. 2016). Geomorphosites are recognised for having three peculiarities in relation to other categories: the imbrication of spatial and temporal scales, the dynamic dimension and the aesthetic dimension (Reynard et al. 2009). Santos et al. (2019) evaluated how these specificities influence the assessment of geomorphosites and concluded that they should be taken into account in order to prevent mistakes and misjudgements with the final result. These authors also highlighted the importance of the ecological and cultural values for geomorphosites, which are not specificities but are highly relevant in geomorphological contexts. Geomorphosites can be considered as the category with the broadest set of associated values (Coratza and Hobléa 2018).

Mucivuna et al. (2019) presented a research of great importance concerning methodological issues on the creation of inventories and the qualitative and quantitative assessment of geomorphosites. These authors performed a review of dozens of articles in order to analyse how the methods are being applied. First, concerning the qualitative assessment, they concluded that the methods should be more systematic since many are not transparent with the procedures and criteria used to select and describe the geomorphosites $(70 \%$ of the analysed articles did not specify the criteria used to select geomorphosites and $44 \%$ of them did not present standardised methods), making it difficult to reproduce them. Second, concerning the quantitative assessment, there is confusion on how and which criteria should be used, since problems like using the same criteria with different aims or overlapping criteria are common. Their research also showed that there are many methods published as "new", which are highly similar to previously existing methods.

The aim of this work is to present a method for inventorying and assessing geomorphosites, advancing in issues that still need improvements, like how to assess different values in an integrated manner and how to deal with the specificities of geomorphosites in assessment procedures. It assesses the scientific, educational and geotouristic values as representative of the use potentials of the sites. It also assesses the conditions for promotion and the risks of degradation. The objective is to create a product to support environmental management, focused on the geoconservation and sustainable use of geomorphosites. The method was applied to the southeast coast of Rio de Janeiro 
State, Brazil, which is a region of high geoscientific relevance and an important touristic destination.

\section{STUDY AREA}

The proposed method was tested in the southeast coast of Rio de Janeiro State, Brazil (Fig. 1), which is inside the territory of the proposed Costões e Lagunas (cliffs and lagoons) geopark. The area is recognised for its high geodiversity and it has been the target of multiple geological and geomorphological studies for decades (e.g Martin et al. 1996; Turcq et al. 1999; Thomaz-Filho et al. 2005; Schmitt et al. 2016) It is also one of the most important tourist destinations of the whole country due to the high number of beaches with great scenic beauty.
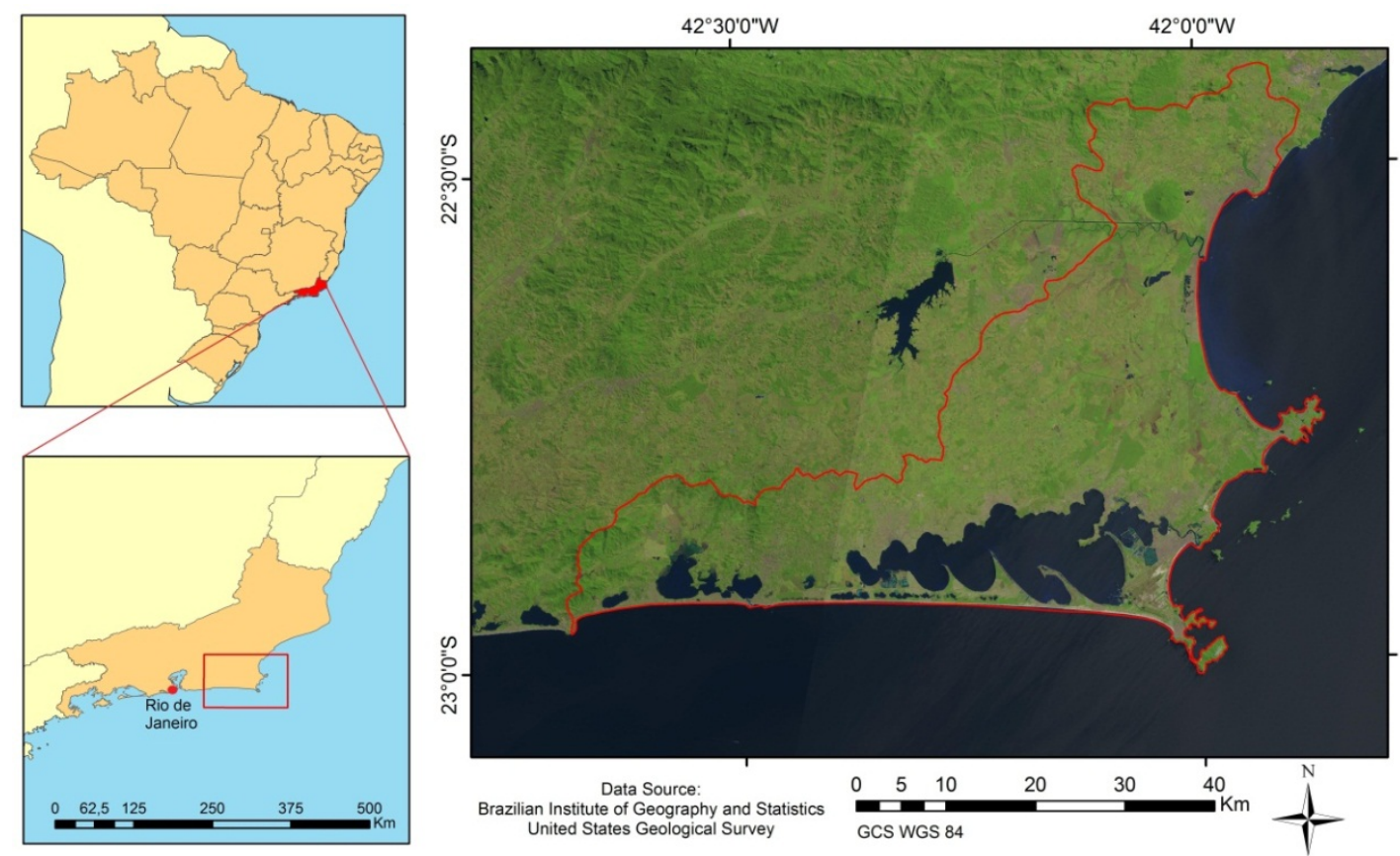

Fig. 1: Location of the study area - southeast coast of Rio de Janeiro State, Brazil.

The geomorphological setting of the area is determined by processes with very different spatial and temporal scales, ranging from tectonic movements related to the opening of the Atlantic Ocean to Holocene sea level variations and anthropic activities (Martin et al. 1996; Castro et a. 2014; Schmitt et al. 2016). Ten types of geomorphological units were identified in the study area, namely: coastal massifs, alkaline massifs, double barrier-lagoon systems, palaeolagoons, marine terraces, cliffs and palaeocliffs, lagoonal spits, dune fields, beaches and cultural landscapes (anthropic landforms).

The coastal massifs (Fig. 2A) are related to the tectonic movements related to the opening of the South Atlantic Ocean, between the Upper Jurassic and Lower Cretaceous. In this context, a series of rifting processes uplifted the mountain ranges which are, nowadays, parallel to the Atlantic Ocean coastline and the lower coastal massifs (Asmus and Ferrari 1978; Zalán and Oliveira 2005). The alkaline massifs are part of the magmatic alignment called Poços de Caldas-Cabo Frio, which consists of several massifs composed of alkaline rocks stretching for more than $480 \mathrm{~km}$ in an east-west direction. 
The genesis of this landform is related to the movement of the South-American plate over a hotspot (Thomaz-Filho et al. 2005).

During the Quaternary, sea level variations were responsible for the genesis of several features in the coastal plain (Martin et al. 1996). The portion of the coastline facing south is characterised by the presence of a double barrier-lagoon system. The inner barrier was formed during the Pleistocene transgressive event, around 123,000 years BP, when the Araruama Lagoon was formed. During the following regression, many lagoons passed through drying processes and wilted or even disappeared, originating a series of palaeolagoon deposits which are present in today's coastal plain (Fig.2B). The external barrier was formed during the Holocene Maximum Transgression, around 5,100 years $\mathrm{BP}$, when a series of lagoons were formed between the inner and the external barriers. Sea level oscillations during the Holocene are also responsible for the existence of marine terraces and palaeocliffs (Fig. 2C), which were originated by coastal processes but are now located above sea level, no longer being affected by these processes.

At present, the region is marked by a climatic peculiarity. While most of Rio de Janeiro State is characterised by a humid tropical climate, the southeast coast has a semiarid climate. The main reasons for this peculiarity is the geomorphological setting, since the region is a coastal plain distant from the mountain ranges that "block" humidity from the ocean and it is affected by upwelling phenomena, in which cold waters from the Malvinas current come to the surface, inhibiting the formation of clouds (Barbiére 1975). This climatic peculiarity allows the establishment of dune fields (Fig. 2D), which are mainly aligned with the predominant NE winds. These dune fields are formed by a "simple" process: waves in the ocean deposit sand in the coast and the winds remove the fine sediments, depositing them in the coastal plain (Fernandez et al. 2009).

Other interesting geomorphological features related to the climatic peculiarity are the Salinas cultural landscapes (Fig. 2E). Due to the lack of rains and intense insolation, the production of salt by natural evaporation in tanks took place as a historical economic activity. This economic activity created an anthropic landform characterised for being totally flat, eventually with shallow water. These landscapes are now recognised as a cultural heritage of the region.

The Araruama Lagoon is the largest hypersaline lagoon in Brazil and one of the largest in the world (Debenay et al. 2001). Its northern shore is composed of basement rocks while the southern shore is the inner barrier, formed during the Pleistocene. Windgenerated waves are responsible for the formation of a series of cuspate spits (Fig. 2F) with a northwest orientation inside the lagoon, in conformity with the predominant NE winds. These winds generate waves that have an angle between their crests and the shoreline, creating a sediment flux, since the southern shore is a sand barrier. When highangle waves reach a perturbation in the shoreline, the changes in the angle provokes, initially, an increase in the sediment flux in the inflection point, causing erosion. Then the angle becomes continuously smaller, causing a decrease in sediment flux and, consequently, accumulation in the crest of the feature. As the spit grows longer, it creates a "shadow-zone" for the main wave action downdrift. It allows the activity of weaker waves that create a counter-debris stream filling the cavity between the spit and the shore. Another spit is formed, then, by the same processes occurring beyond this "shadow- 
295

zone". This type of process is described in works such as Zenkovitch (1959) and Ashton et al. (2001).

Finally, the region is characterised by a great variety of beaches with high scenic beauty. Because of that, tourism is the main source of income in most of the municipalities. Due to local conditions, there are several types of beaches. The coastline facing south, for instance, presents great barriers with a clear east-west orientation (Fig. $2 \mathrm{G}$ ). The coastline facing east, in the other hand, presents several coves (Fig. 2H) and beaches with different shapes and morphodynamic profiles.

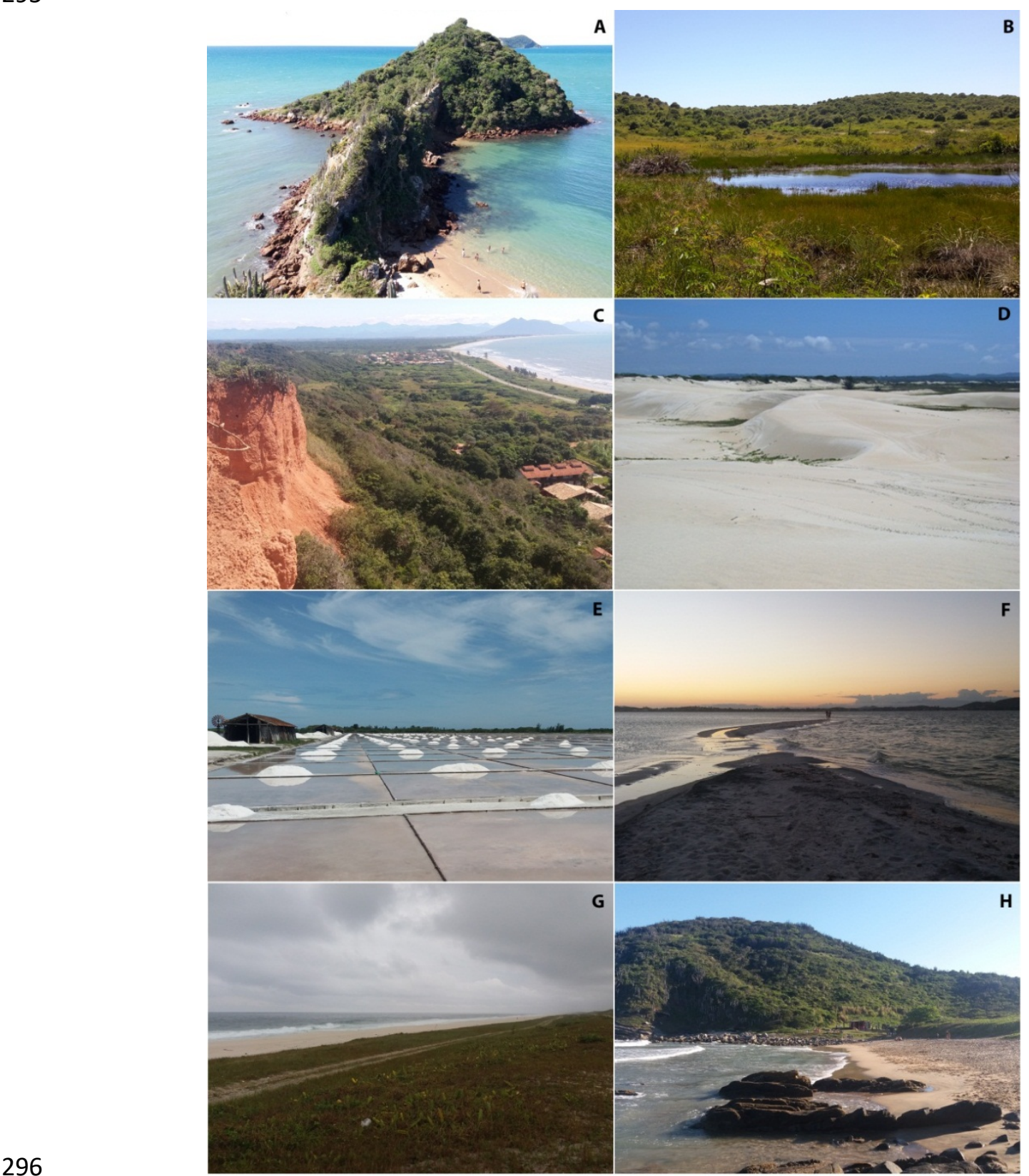

Fig. 2: (A) Coastal massif in Pai Vitório Point; (B) Wetlands related to palaeolagoons in cultural landscape; (F) Edge of a cuspate spit in Araruama Lagoon; (G) Coastal barrier in 


\section{METHODOLOGICAL PROCEDURES}

The method was divided into three main steps: preliminary assessment, characterisation and quantitative assessment. The first consists of the selection of geomorphosites to be included in the inventory and the two further steps are the complete assessment of the site.

\section{Preliminary assessment}

The pre-selection is one of the most unclear steps in the methods proposed so far (Pereira and Pereira 2010; Reynard et al. 2016; Sellier 2016; Mucivuna et al. 2019). Geodiversity comprises all elements of the physical environment and, as highlighted by Brilha (2016, 2018), choosing the ones that must be conserved for the benefits of present and future generations is a major challenge in geoconservation. Therefore, when a method is not clear about the procedures, it becomes hard, sometimes impossible, to reproduce it in other areas, resulting in the creation of new methods instead of using previous ones (Mucivuna et al. 2019).

Some works, such as Coratza and Giusti (2005) and Serrano and González-Trueba (2005), present indications on how to select the sites that will be evaluated. Coratza and Giusti (2005) highlighted the use of GIS in this step, using geomorphological maps and DTMs for an initial investigation. The method of Serrano and González-Trueba (2005) used geomorphological maps as basic tools to identify geomorphosites. Both works state that the knowledge about the geomorphological setting of the area is crucial for the inventory. However, the parameters used for selecting the sites are not clear enough to be reproduced by other researchers, since there is still a high degree of subjectivity.

The method proposed by Pereira and Pereira (2010) is one of the first to present a pre-selection phase, in which potential geomorphosites are identified and qualitatively evaluated under a clear set of criteria. The identification is based on a geomorphological survey of the area through bibliographic research and fieldwork. The scientific relevance, aesthetic component and the links with cultural and ecological elements are the criteria used in this stage. The preliminary evaluation consists of a qualitative assessment of the scientific, ecological, cultural and aesthetic values and parameters of use and management, including need of protection. The final selection is based on the performance of the sites in this first evaluation.

The method proposed by Brilha (2016), designed not only for geomorphosites but for any category of geosites, also proposes a clear pre-selection phase. This author presented a conceptual review and its method is divided in sites with scientific value (geosites) and sites with educational and touristic relevance (geodiversity sites). The preselection phase consists of bibliographic review followed by fieldwork, when the sites are characterised and evaluated taking into account their representativeness, integrity, rarity and scientific knowledge if they are potential geosites; and their didactic potential, geological diversity, accessibility, safety, aesthetic component and interpretive potential if they are potential geodiversity sites. 
Sellier (2016) focused on the geomorphological context, bringing the idea that an inventory should provide an overview of the geomorphology of the study area. Reynard et al. (2016) followed this idea, proposing a selection method divided in four steps: (1) definition of the main geomorphological contexts (morphostructures, geomorphological processes etc.); (2) creation of a preliminary list of landforms including each geomorphological context; (3) classification of the landforms based on spatial and temporal criteria; (4) selection of geomorphosites, with the creation of a list that is representative of the geomorphology of the study area, covering the diversity of landforms and the morphogenetic phases.

The methodology proposed here starts with a pre-selection phase, called Preliminary Assessment. It is based on the main issues highlighted on previous proposals and is divided in the following steps:

1. Following Sellier (2016) and Reynard et al. (2016), the first step is the definition of the geomorphological contexts of the area. Serrano and González-Trueba (2005) used geomorphological maps as basic tools to select geomorphosites. However, especially in large countries, like Brazil, there is a lack of data in many areas and developing geomorphological maps as a mandatory condition for creating inventories is unfeasible for being time consuming and for the significant elevation of costs. Therefore, we endorse that geomorphological maps should be used but, if they do not exist in an area, this first step must be done with other materials (remote sensing products, other thematic maps, bibliographic and field survey etc.).

2. Selection of sites in each context considering the representativeness of the landforms. Following Reynard et al. (2016) proposal, this step must take into account spatial and temporal criteria, so that the inventory may cover both the geomorphological diversity and the morphogenetic phases. The sites must be selected by their scientific relevance, but also by their educational and touristic use potentials, as in Brilha (2016). This step ends up with the creation of a preliminary list of sites.

3. Assessment of the sites according to the parameters and scores displayed in Table 1. This step was mainly based on the work of Pereira and Pereira (2010), with some modifications on the parameters. The main goal of this step is to avoid the inclusion of non-relevant sites in the following procedures (characterisation and quantitative assessment), which are time consuming and demand a lot of effort. Only the sites with high scores are selected. There is not a specific score to be achieved. The evaluator can decide what the minimum score is taking into account specific issues of his work. The only recommendations are: sites with Very High rarity must be chosen; Sites with low scores on Additional Parameters and Use and Management Parameters, but high values on the Central Parameters, should not be excluded; and there must be at least one site representing each geomorphological context. By the end of this step, a final list is created with the sites that will be included in the inventory. 
Table 1: Criteria and scores for the Preliminary Assessment of sites.

\begin{tabular}{|c|c|c|}
\hline \multicolumn{2}{|c|}{ Criteria } & Assessment \\
\hline Central Parameters & $\begin{array}{l}\text { Representativeness } \\
\text { Integrity } \\
\text { Rarity } \\
\text { Scientific knowledge }\end{array}$ & $\begin{array}{l}1 \text { - Low } \\
2 \text { - Medium } \\
3 \text { - High } \\
4-\text { Very high }\end{array}$ \\
\hline Additional Parameters & $\begin{array}{l}\text { Ecological relevance } \\
\text { Cultural relevance } \\
\text { Aesthetic relevance }\end{array}$ & $\begin{array}{l}0-\text { None } \\
1-\text { Low } \\
2-\text { Medium } \\
3-\text { High }\end{array}$ \\
\hline $\begin{array}{l}\text { Use and Management } \\
\text { Parameters }\end{array}$ & $\begin{array}{l}\text { Accessibility } \\
\text { Safety } \\
\text { Infrastructure } \\
\text { Visibility }\end{array}$ & $\begin{array}{l}1-\text { Low } \\
2-\text { Medium } \\
3-\text { High }\end{array}$ \\
\hline
\end{tabular}

\section{Characterisation and quantitative assessment}

After the preliminary assessment, each selected site passes through a process of characterisation of its geomorphological aspects, associated interests and use and management issues. This step is not only essential for the final results, but also to provide the necessary information for the quantitative assessment. Similarly to the preliminary assessment, previous proposals were analysed in order to propose the method used in this work.

The use of descriptive cards for the characterisation is common (e.g Serrano and González-Trueba 2005; Pereira and Pereira 2010) and it is an effective way to standardise the information. Other authors (e.g Brilha 2016; Reynard et al. 2016) do not use descriptive cards, but clearly describe which information must be included. For this work, a descriptive card is proposed (Table 2), being mainly based on the work of Serrano and González-Trueba (2005) and considering issues highlighted in other works. The spatial classification is based on Grandgirard (1999) and Perret (2014) (Fig. 3). This classification is related to the spatial complexity of the geomorphosite according to the processes and landforms, being also important for the creation of a vector database in GIS, which is not mandatory, but strongly recommended. However, different from some authors (e.g Pereira and Pereira 2010; Rodrigues 2013; Migón and Pijet-Migón 2017), viewpoints are not considered as geomorphosites in this work, being considered a place to visualise geomorphosites or landscapes. Geomorphosites are geomorphological features presenting certain values that the viewpoints themselves do not have, since they can even be totally man-made (in accordance with Santos et al. 2019). 
Table 2: Characterisation of geomorphosites including the quantitative assessment results.

\begin{tabular}{|c|c|}
\hline \multirow{4}{*}{ Identification } & Name \\
\hline & Location \\
\hline & Property \\
\hline & Eventual use limitations \\
\hline \multirow{7}{*}{ Geomorphology } & Thematic classification (coastal, aeolian, glacial, tectonic etc.) \\
\hline & Spatial classification (according to Figure 3 ) \\
\hline & Size/ Area \\
\hline & Altitude \\
\hline & Landforms: active and inactive (when applicable) \\
\hline & $\begin{array}{l}\text { Processes: active, inactive or passive evolving geomorphosite (based on Pelfini and } \\
\text { Bollati 2014) (when applicable) }\end{array}$ \\
\hline & Morphogenesis (morphogenetic history) \\
\hline Associated interests & $\begin{array}{l}\text { Brief explanation of each associated interest (high geodiversity, other areas of } \\
\text { geosciences, ecological, cultural etc.) }\end{array}$ \\
\hline \multirow{9}{*}{ Use and Management } & $\begin{array}{l}\text { Access (from closest city or village): Public/ private transport; Trails; Access to } \\
\text { wheelchairs (takes into account the possibility of existence of different specific } \\
\text { viewpoints). }\end{array}$ \\
\hline & $\begin{array}{l}\text { Safety. Takes into account the type of visitors, size of groups and inherent risks of the } \\
\text { site. }\end{array}$ \\
\hline & Observation conditions. \\
\hline & Interpretive potential and existence of interpretive material. \\
\hline & Infrastructure on the site. \\
\hline & Regional touristic infrastructure. \\
\hline & Integrity and protection status. \\
\hline & Fragility. \\
\hline & Natural and anthropic vulnerability. \\
\hline Quantitative assessment & Graphic presenting the quantitative assessment results \\
\hline Photos & \\
\hline
\end{tabular}

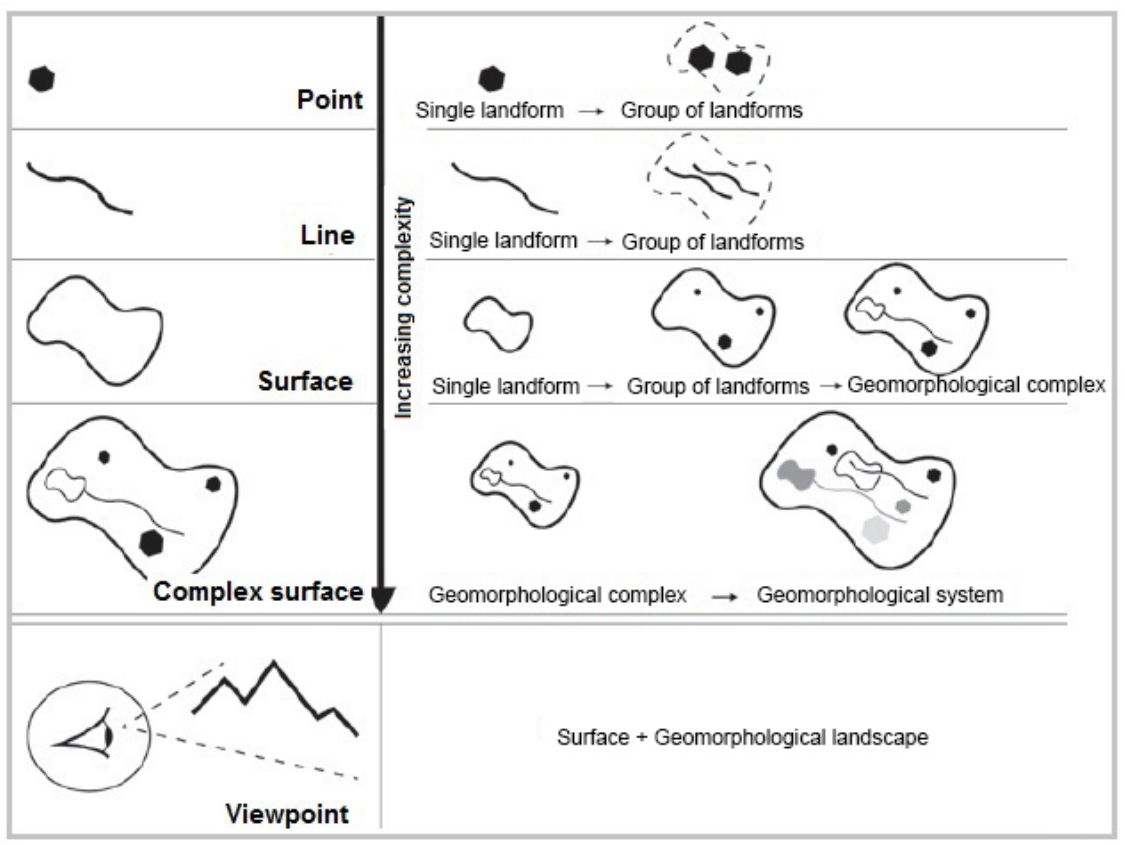

Fig. 3: Spatial classification of geomorphosites (translated from Perret 2014).

The quantitative assessment is still a subject of discussion, with dozens of different methods proposed so far (Mucivuna et al. 2019). A basic idea is that the methods must be in conformity with the aim of the inventory. A method focused on creating an 
inventory of sites with scientific relevance, for instance, would not consider parameters such as aesthetic value. An inventory focused on geotourism, on the other hand, would definitely take this parameter into account, since the aesthetic dimension is quite important to attract tourists and raise awareness about the importance of geomorphology for the society as a whole (Goudie 2002). Therefore, the parameters included in a method must have a direct connection with the aim of the inventory.

The method proposed here is focused on the use potential of the site, dividing it into three types: scientific use, educational use and geotouristic use. Besides that, the method is intended to assess the promotion potential of the site, which is the assessment of the visiting conditions in order to find out if the site is suitable to be promoted for visitors or if it needs managing actions before. Finally, the risks of degradation are also quantitatively assessed, since this is a fundamental issue in geoconservation. Therefore, three values are assessed to represent the use potential, namely the scientific, educational and geotouristic values. The ecological, cultural and aesthetic values are used as parameters to assess the use values and are also displayed as additional values in the final result because of their importance for geomorphosites.

Despite the existence of different methods because of their different aims, it is clear that many of the criteria used are similar. Pralong (2005), for instance, presented a method to assess the tourist potential of sites and included, among others, the scientific value as a parameter. Bollati et al. (2012) presented a method focused on educational purposes and also included the scientific value as a part of the assessment. The same was done by Coratza and Giusti (2005) in their method focused in territorial planning, environmental impact assessment and protection of the natural heritage. Due to the importance of the scientific value, authors such as Pereira and Pereira (2010), Brilha (2016) and Reynard et al. (2016) put it as central values in their methods, while other values are considered as additional.

Considering that the method proposed here is focused on the scientific, educational and geotouristic use of the sites and that methods proposed so far use similar criteria despite having different aims, a set of criteria was selected to assess these values, being called Basic Parameters. Considering the work of Bruschi et al. (2011) that shows that a high number of parameters does not translate into a more accurate assessment, the choice of the Basic Parameters considered some of those most used in previous proposals, being careful not to use parameters that are too similar.

The Basic Parameters are: representativeness, integrity, rarity, geodiversity, interpretive potential, scientific knowledge and observation conditions. They were chosen for being present in some of the most important existing proposals (e.g Pereira and Pereira 2010; Brilha 2016; Reynard et al. 2016). The palaeogeographic value was considered part of the representativeness, since landforms with palaeogeographic value are actually representing a part of the history of the Earth, and thus do not need to be assessed separately.

Some proposals include the ecological value as part of the scientific value and highlight its importance for educational and touristic purposes (e.g Panizza 2001; Pralong 2005, Bollati et al. 2012). For this reason, it was also included in the assessment. The cultural value was also included for considering the importance of cultural 
geomorphology; so it was not considered only an additional value, but part of the scientific and educational values. The importance of the cultural value for geotourism is also stressed in previous works (e.g Pralong 2005; Coratza et al. 2016). However, sites presenting relevant ecological and cultural values are not so common; so it was decided to consider one or the other in the assessment instead of both. Finally, the aesthetic value was included especially due to its importance for geotourism, but also for presenting relevance in educational activities, since the aesthetic dimension also attracts the attention of students and people taking part in educational projects. It is important to highlight that these values (ecological, cultural and aesthetic) are used to assess the scientific, educational and geotouristic values but must also be presented as additional in the final results.

The same parameters were used to assess different values, but it would be wrong to consider that they always have the same importance. For this reason, a weighting scheme was proposed to assess the scientific, educational and geotouristic values, as displayed in Table 3. The indicators to assess the basic parameters are presented in Table 4 and the additional values in Table 5 .

Table 3: Parameters to assess the scientific, educational and geotouristic values and the weighting scheme.

\begin{tabular}{|l|l|l|l|}
\hline & $\begin{array}{l}\text { Scientific } \\
\text { value }\end{array}$ & $\begin{array}{l}\text { Educational } \\
\text { value }\end{array}$ & $\begin{array}{l}\text { Geotouristic } \\
\text { value }\end{array}$ \\
\hline Representativeness & $30 \%$ & $20 \%$ & $10 \%$ \\
\hline Integrity & $20 \%$ & $10 \%$ & $15 \%$ \\
\hline Rarity & $15 \%$ & $10 \%$ & $10 \%$ \\
\hline Geodiversity & $5 \%$ & $5 \%$ & $5 \%$ \\
\hline Interpretive potential & $0 \%$ & $15 \%$ & $15 \%$ \\
\hline Scientific knowledge & $10 \%$ & $10 \%$ & $0 \%$ \\
\hline Observation conditions & $10 \%$ & $15 \%$ & $15 \%$ \\
\hline Ecologic or cultural value & $10 \%$ & $10 \%$ & $10 \%$ \\
\hline Aesthetic value & $0 \%$ & $5 \%$ & $20 \%$ \\
\hline
\end{tabular}

Some methods for the assessment of geomorphosites present different weights to calculate the final values; however, their authors do not justify the reasons for that (Mucivuna et al. 2019). In the method proposed here, the weightings were applied in order to stress that some parameters have higher importance than others.

Representativeness, integrity and rarity are three of the most used criteria to assess the scientific value of geosites (Mucivuna et al. 2019), so they have a higher importance for the scientific value in the proposed method, adding up to $65 \%$ of the total. These criteria have a slight lower relevance for the educational and geotouristic values because other criteria were considered equally or more important (interpretive potential and observation conditions). The aesthetic value is considered the most important for the geotouristic value due to the attractiveness of the aesthetic dimension for the public in general. Scientific knowledge represents the current scientific use of the site and the weight of $10 \%$ was given to address that fact; it is not higher because it is common that sites have a high potential but are not yet very used. Geodiversity is considered because the variety of elements may be an interesting characteristic, but, since it is not 
"mandatory" to have diversity of elements to be important, the weight given to this parameter is low.

\begin{tabular}{|c|c|}
\hline \multirow{4}{*}{ Representativeness } & $\begin{array}{l}\text { 0.25: The site represents a form or process of the regional } \\
\text { geomorphological context. }\end{array}$ \\
\hline & $\begin{array}{l}\text { 0.5: The site is the best example of some geomorphological unit of process } \\
\text { of the regional geomorphological context. }\end{array}$ \\
\hline & $\begin{array}{l}\text { 0.75: The site represents a clear relation between forms and processes or } \\
\text { the site has palaeogeographic relevance. }\end{array}$ \\
\hline & $\begin{array}{l}\text { 1.0: The site represents a clear relation between forms and processes and } \\
\text { the site has palaeogeographical relevance. }\end{array}$ \\
\hline \multirow{4}{*}{ Integrity } & 0.25: The forms and/or processes are significantly altered. \\
\hline & $\begin{array}{l}\text { 0.5: The forms and/or processes are significantly altered, but it is still } \\
\text { possible to clearly recognize and analyse them. }\end{array}$ \\
\hline & $\begin{array}{l}\text { 0.75: The forms and/or processes are not intact, but are not significantly } \\
\text { altered. }\end{array}$ \\
\hline & 1.0: The forms and/or processes are intact. \\
\hline \multirow{4}{*}{ Rarity } & 0. 25: The site represents a common form/ process in the area. \\
\hline & 0.5: The site is the best example of a common form/process in the area. \\
\hline & 0.75: There are few examples of the form/process represented by the site. \\
\hline & 1.0: The site is the only occurrence of the type in the study area. \\
\hline \multirow{4}{*}{ Geodiversity } & 0.25 : The site represents a geomorphological complex. \\
\hline & 0.5: The site represents a geomorphological system. \\
\hline & $\begin{array}{l}0.75 \text { : The site presents relevant elements beyond geomorphology (other } \\
\text { aspects of geodiversity). }\end{array}$ \\
\hline & $\begin{array}{l}\text { 1.0: The site presents three or more relevant elements beyond } \\
\text { geomorphology (other aspects of geodiversity). }\end{array}$ \\
\hline \multirow{4}{*}{ Scientific knowledge } & $\begin{array}{l}\text { 0.25: There is scientific material available (monographies, abstracts, } \\
\text { simple reports etc.). }\end{array}$ \\
\hline & $\begin{array}{l}\text { 0.5: The site was used for the development of master dissertations or it is } \\
\text { currently used for the development of not yet published research. }\end{array}$ \\
\hline & $\begin{array}{l}\text { 0.75: There are works about the geomorphological features of the site } \\
\text { published in national journals or books with national relevance or the site } \\
\text { was used for the development of doctoral theses. }\end{array}$ \\
\hline & $\begin{array}{l}\text { 1.0: There are works about the geomorphological features of the site } \\
\text { published in international journals or books with international relevance. }\end{array}$ \\
\hline \multirow{4}{*}{ Observation conditions } & $\begin{array}{l}0.25 \text { The observation of the elements is very hard, depending on specific } \\
\text { conditions. }\end{array}$ \\
\hline & $\begin{array}{l}\text { 0.5: The observation of the elements is hard, but it does not depend on } \\
\text { specific conditions. }\end{array}$ \\
\hline & 0.75: There are few difficulties for the observation of the elements. \\
\hline & 1.0: There are no obstacles for the observation of the elements. \\
\hline \multirow{3}{*}{ Interpretive potential } & 0.25 : Suitable only for students of geosciences. \\
\hline & $\begin{array}{l}\text { 0.5: Some basic geoscientific knowledge is necessary to interpret the site } \\
\text { (scholar level). }\end{array}$ \\
\hline & 0.75: Suitable for youth and adults. \\
\hline
\end{tabular}

Table 4: Indicators to assess the basic parameters. 
Table 5: Indicators to assess the Additional Values.

\begin{tabular}{|c|c|}
\hline \multirow{4}{*}{ Ecological value } & $\begin{array}{l}\text { 0.25: The geomorphological unit represented by the geomorphosite has } \\
\text { direct relationship with some biotic aspect. }\end{array}$ \\
\hline & $\begin{array}{l}\text { 0.5: The geomorphological unit represented by the geomorphosite has } \\
\text { direct relationship with some special biotic aspect (rare, endemic, } \\
\text { threatened etc.). }\end{array}$ \\
\hline & $\begin{array}{l}0.75 \text { : The site shows a clear conditioning of geomorphology over some } \\
\text { biotic aspect. }\end{array}$ \\
\hline & $\begin{array}{l}\text { 1.0: The site represents a special case of relationship between } \\
\text { geomorphology and biodiversity. }\end{array}$ \\
\hline \multirow{4}{*}{ Cultural value } & $\begin{array}{l}0.25 \text { : There are elements with cultural importance, but not directly related } \\
\text { to the geomorphological setting. }\end{array}$ \\
\hline & $\begin{array}{l}\text { 0.5: There are elements with cultural importance directly related to the } \\
\text { geomorphological setting or the site has economic importance. }\end{array}$ \\
\hline & $\begin{array}{l}\text { 0.75: The site is/was occupied or is highly relevant for some traditional } \\
\text { community or the site was used for the development of a } \\
\text { geomorphological model. }\end{array}$ \\
\hline & $\begin{array}{l}\text { 1.0: The main geomorphological feature is anthropic, or represents an } \\
\text { icon of a people/region, or is highly relevant for the history of } \\
\text { geomorphology. }\end{array}$ \\
\hline \multirow{4}{*}{$\begin{array}{l}\text { Aesthetic value 1: Visualisation } \\
\text { conditions }\end{array}$} & $\begin{array}{l}\text { 0.25: There are significant difficulties to visualize the site, being } \\
\text { impossible to see it in its totality. }\end{array}$ \\
\hline & $\begin{array}{l}\text { 0.5: There are significant difficulties to visualize the site, but it is possible } \\
\text { to see it in its totality. }\end{array}$ \\
\hline & $\begin{array}{l}0.75 \text { : The site can be seen with no difficulties, but only from specific } \\
\text { viewpoints. }\end{array}$ \\
\hline & $\begin{array}{l}\text { 1.0: The site can be seen with no difficulties without the need of going to } \\
\text { specific viewpoints. }\end{array}$ \\
\hline \multirow{4}{*}{ Aesthetic value 2: Conservation } & $0.25:$ Site highly altered/ degraded. \\
\hline & 0.5: Site partially altered/ degraded. \\
\hline & 0.75: Site with alterations but with low influence on its aesthetics. \\
\hline & 1.0: Site in very good state of conservation. \\
\hline \multirow{4}{*}{$\begin{array}{l}\text { Aesthetic value 3: Aesthetic } \\
\text { dimension }\end{array}$} & 0.25: Low (the aesthetic dimension does not contribute to attract visitors). \\
\hline & $\begin{array}{l}\text { 0.5: Medium (the aesthetic dimension may be attractive to a specific } \\
\text { public). }\end{array}$ \\
\hline & $\begin{array}{l}0.75 \text { : High (the aesthetic dimension may highly contribute to attract } \\
\text { visitors). }\end{array}$ \\
\hline & $\begin{array}{l}\text { 1.0: Exceptional (site already widely recognised by its aesthetic } \\
\text { dimension). }\end{array}$ \\
\hline Aesthetic value & $(\mathrm{AV} 1+\mathrm{AV} 2+\mathrm{AV} 3) / 3$ \\
\hline
\end{tabular}

The aesthetic value is one of the most subjective, being difficult to quantify. The parameters proposed here take into account not "how beautiful the site is", since it would be impossible to answer this question with a score. Assessing the visualisation conditions is considered part of the aesthetic value because the method is focused on the use potentials of the site, so sites where the fruition of the aesthetic dimension is facilitated should have higher values. The conservation is also taken into account because a degraded site loses its characteristics, which may influence its aesthetics depending on the degree of alteration. Finally, the aesthetic dimension parameter is the most subjective one, since it depends more on the evaluator. This parameter is assessed based on the potential of the site to attract visitors due to its aesthetics, with the highest values being given to the sites that are already recognised by the wide public.

After the assessment of values, comes the assessment of use and management parameters, which are divided into Promotion and Risks of Degradation. Similarly to Reynard et al. (2016), use and management characteristics are not considered values of the sites. However, different from the cited authors, it does not mean that they should not 
be quantitatively assessed. It is only important to make it clear that this is an assessment of the current conditions for use and risks of degradation and it may change if management actions are taken. In fact, this is the point in performing this quantitative assessment: to provide a tool for managers that make it easier to identify sites that need attention, such as sites with high values and high risks of degradation or inadequate conditions to receive visitors.

Table 6 presents the indicators to assess Promotion parameters, which are: access by public transport; access by private transport; need for walking/hiking; natural risks; human risks; safety for groups; infrastructure in the site; regional touristic infrastructure. All parameters were considered equally important; so no weighting is proposed for this assessment (the total value is the arithmetic mean). Table 7 presents the indicators for the Risks of Degradation, being: legal and indirect protection; access; fragility; anthropic vulnerability; natural vulnerability; use conflicts. The weighting for these parameters is presented on Table 8 .

The main inspiration for the assessment of Risks of Degradation was the work of García-Ortiz et al. (2014). The parameters "access" and "legal and indirect protection" were inspired by the work of Brilha (2016).

Table 6: Indicators for the assessment of Promotion parameters.

\begin{tabular}{|c|c|}
\hline \multirow{4}{*}{ Access by public transport } & 0.25 : Low frequency and distant from the site. \\
\hline & 0.5: Low frequency but close to the site. \\
\hline & 0.75: Frequent but distant from the site. \\
\hline & 1.0: Frequent and close to the site. \\
\hline \multirow{4}{*}{ Access by private transport } & 0.25: Need of specific vehicles. \\
\hline & 0.5 : It is possible to visit with regular vehicles. \\
\hline & 0.75 : Good roads and parking area or parking area for bus. . \\
\hline & 1.0: Good roads and parking area for bus. \\
\hline \multirow{4}{*}{ Need for walking/ hiking } & 0.25: Hiking with technical difficulties. \\
\hline & $\begin{array}{l}\text { 0.5: Long and technically easy walk or short and technically easy walk, but } \\
\text { inaccessible for disabled visitors. }\end{array}$ \\
\hline & 0.75 : Short and technically easy walk, accessible for disabled visitors. \\
\hline & 1.0: No need to walk. \\
\hline \multirow{4}{*}{ Natural risks } & 0.25: Dangerous environment, with risks of serious accidents. \\
\hline & $\begin{array}{l}\text { 0.5: Small risk of accidents or risk of serious accidents due to inadequate } \\
\text { behaviour. }\end{array}$ \\
\hline & 0.75 : Small risk of accidents due to inadequate behaviour. \\
\hline & 1.0: Safe environment. \\
\hline \multirow{4}{*}{ Human risks } & 0.25 : Problems related to violence. \\
\hline & 0.5: Site located along dangerous road. \\
\hline & 0.75 : Site with no safety infrastructure. \\
\hline & 1.0: Safe environment (site has safety infrastructure or does not need any). \\
\hline \multirow{4}{*}{ Safety for groups } & 0.25: Group visits demand special care. \\
\hline & 0.5: Safe for small groups. \\
\hline & 0.75: Safe for groups of adults. \\
\hline & 1.0: Safe for groups with children. \\
\hline \multirow{4}{*}{ Infrastructure in the site } & 0.25 : Site with eventual infrastructure (high season, weekends etc.). \\
\hline & $\begin{array}{l}\text { 0.5: Site with interpretive infrastructure but no other infrastructure for } \\
\text { visitors. }\end{array}$ \\
\hline & 0.75: Site with infrastructure for visitors (bathrooms, shops etc.). \\
\hline & 1.0: Site with both interpretive and visiting infrastructure. \\
\hline \multirow{3}{*}{ Regional touristic infrastructure } & $\begin{array}{l}0.25 \text { : The closest city/village with touristic infrastructure is less than three } \\
\text { hours away by car/bus. }\end{array}$ \\
\hline & $\begin{array}{l}\text { 0.5: The closest city/village with touristic infrastructure is located around } \\
\text { one hour away by car/bus. }\end{array}$ \\
\hline & $\begin{array}{l}\text { 0.75: The site is located in the surroundings of a city/village with touristic } \\
\text { infrastructure. }\end{array}$ \\
\hline
\end{tabular}


Table 7: Indicators for the assessment of Risks of Degradation.

\begin{tabular}{|c|c|}
\hline \multirow{4}{*}{ Legal and indirect protection } & $\begin{array}{l}\text { 0.25: Site located in protected area with no control of access, but with the } \\
\text { presence of communities, associations or groups that effectively protect the } \\
\text { site. }\end{array}$ \\
\hline & $\begin{array}{l}\text { 0.5: Site located in protected area with no control of access or site with no } \\
\text { legal protection but with the presence of communities, associations or } \\
\text { groups that effectively protect the site. }\end{array}$ \\
\hline & $\begin{array}{l}0.75 \text { : Site with no legal protection and with reduced action of communities, } \\
\text { associations or groups protecting it. }\end{array}$ \\
\hline & 1.0: Site with no legal or indirect protection. \\
\hline \multirow{4}{*}{ Access } & $\begin{array}{l}0.25 \text { : Access by long walk with no technical difficulties or short walk with } \\
\text { technical difficulties. The walk starts in non-paved road, but accessible by } \\
\text { bus. }\end{array}$ \\
\hline & $\begin{array}{l}\text { 0.5: Site located close to non-paved road, but accessible by bus. May } \\
\text { include short and easy walk. }\end{array}$ \\
\hline & $\begin{array}{l}0.75 \text { : Access by long walk with no technical difficulties or short walk with } \\
\text { technical difficulties. The walk starts in paved road, easily accessed by car } \\
\text { or public transport. }\end{array}$ \\
\hline & $\begin{array}{l}\text { 1.0: Site located close to paved road, easily accessed by car or public } \\
\text { transport. May include short and easy walk. }\end{array}$ \\
\hline \multirow{4}{*}{ Anthropic vulnerability } & $\begin{array}{l}0.25: \text { Forms/processes vulnerable to large scale interventions on the site or } \\
\text { related areas, but with no problems related to visits. }\end{array}$ \\
\hline & $\begin{array}{l}\text { 0.5: Forms/processes vulnerable to small scale interventions on the site or } \\
\text { related areas, but with no problems related to visits. }\end{array}$ \\
\hline & $\begin{array}{l}\text { 0.75: Forms/ processes vulnerable to visits, with the need of special cares } \\
\text { (infrastructure, rules, guides etc.). }\end{array}$ \\
\hline & $\begin{array}{l}\text { 1.0: Forms/processes highly vulnerable to visits, being restricted to } \\
\text { authorised people. }\end{array}$ \\
\hline \multirow{4}{*}{ Natural vulnerability } & $\begin{array}{l}0.25 \text { : Possibility of small alterations on the forms or processes of the site } \\
\text { by geomorphological or climatic processes not related to the site. }\end{array}$ \\
\hline & $\begin{array}{l}\text { 0.5: Possibility of significant alterations on the forms or processes of the } \\
\text { site by geomorphological or climatic processes not related to the site. }\end{array}$ \\
\hline & $\begin{array}{l}\text { 0.75: Possibility of partial destruction of the forms or processes of the site } \\
\text { by geomorphological or climatic processes not related to the site. }\end{array}$ \\
\hline & $\begin{array}{l}\text { 1.0: Possibility of total destruction of the forms or processes of the site by } \\
\text { geomorphological or climatic processes not related to the site. }\end{array}$ \\
\hline \multirow{4}{*}{ Fragility } & $\begin{array}{l}0.25 \text { : Low risk of degradation due to inherent geomorphological conditions } \\
\text { of the site. }\end{array}$ \\
\hline & $\begin{array}{l}\text { 0.5: The geomorphological processes of the site are gradually destroying it } \\
\text { (at the human or historical temporal scale). }\end{array}$ \\
\hline & 0.75: Possibility of total destruction of the site in case of extreme events. \\
\hline & $\begin{array}{l}\text { 1.0: Risk of total destruction in a short period of time due to processes } \\
\text { inherent to the site. }\end{array}$ \\
\hline \multirow{4}{*}{ Use conflicts } & $\begin{array}{l}\text { 0.25: There are use conflicts affecting or preventing the scientific, } \\
\text { educational or geotouristic uses, but they do not impose risks to the site. }\end{array}$ \\
\hline & 0.5: There are use conflicts imposing risks to the site. \\
\hline & 0.75 : There are projects that may destroy the site if put into practice. \\
\hline & $\begin{array}{l}\text { 1.0: The current use or imminent changes may destroy the site in a short } \\
\text { period of time. }\end{array}$ \\
\hline
\end{tabular}

\begin{tabular}{|l|l|}
\hline Legal and indirect protection & $25 \%$ \\
\hline Access & $10 \%$ \\
\hline Anthropic vulnerability & $15 \%$ \\
\hline Natural vulnerability & $15 \%$ \\
\hline Fragility & $25 \%$ \\
\hline Use conflicts & $10 \%$ \\
\hline
\end{tabular}


Table 9: Geomorphosites included in the inventory after the preliminary assessment.

\begin{tabular}{|c|c|c|c|c|}
\hline Site & $\begin{array}{c}\text { Geomorphological } \\
\text { Context }\end{array}$ & $\begin{array}{c}\text { Spatial } \\
\text { Classification } \\
\end{array}$ & Features & Processes \\
\hline $\begin{array}{l}\text { Espinho } \\
\text { Wetlands }\end{array}$ & $\begin{array}{l}\text { Double barrier- } \\
\text { lagoon System }\end{array}$ & $\begin{array}{c}\text { Surface - } \\
\text { Geomorphological } \\
\text { System }\end{array}$ & $\begin{array}{l}\text { Coastal barriers; } \\
\text { lagoons; wetlands; } \\
\text { foredunes; parabolic } \\
\text { dunes }\end{array}$ & $\begin{array}{c}\text { Coastal processes } \\
\text { (active and inactive)/ } \\
\text { lagoonal sedimentation; } \\
\text { aeolian processes } \\
\text { (active) }\end{array}$ \\
\hline $\begin{array}{l}\text { Dama Branca } \\
\text { Dune Field }\end{array}$ & Coastal dunes & $\begin{array}{c}\text { Surface }- \\
\text { Geomorphological } \\
\text { Complex }\end{array}$ & $\begin{array}{l}\text { Foredunes; barchans; } \\
\text { barchanoids; parabolic } \\
\text { dunes; parabolic } \\
\text { megaform dune; } \\
\text { nebkhas }\end{array}$ & $\begin{array}{l}\text { Aeolian processes } \\
\text { (active) }\end{array}$ \\
\hline $\begin{array}{l}\text { Ponta Negra } \\
\text { Promontory }\end{array}$ & Coastal massifs & $\begin{array}{l}\text { Surface }- \text { Single } \\
\text { landform }\end{array}$ & $\begin{array}{l}\text { Rocky promontory } \\
\text { between coastal } \\
\text { barriers }\end{array}$ & $\begin{array}{l}\text { Tectonic processes } \\
\text { (inactive)/ slope } \\
\text { processes (active) }\end{array}$ \\
\hline $\begin{array}{l}\text { Cabo Frio } \\
\text { Island }\end{array}$ & $\begin{array}{l}\text { Alkaline massifs } \\
\quad \text { (island) }\end{array}$ & $\begin{array}{c}\text { Surface - } \\
\text { Geomorphological } \\
\text { System }\end{array}$ & $\begin{array}{l}\text { Island with secondary } \\
\text { features within: beach, } \\
\text { climbing dunes and } \\
\text { sambaquis (anthropic } \\
\text { pre-historic deposits of } \\
\text { sea shells) } \\
\end{array}$ & $\begin{array}{l}\text { Tectonic processes; } \\
\text { anthropic processes } \\
\text { (inactive)/ coastal } \\
\text { processes; aeolian } \\
\text { processes (active) }\end{array}$ \\
\hline $\begin{array}{l}\text { Peró Dune } \\
\text { Field }\end{array}$ & Coastal dunes & $\begin{array}{c}\text { Surface - } \\
\text { Geomorphological } \\
\text { complex }\end{array}$ & $\begin{array}{l}\text { Foredunes; parabolic } \\
\text { dunes; barchanoids; } \\
\text { nebkhas; climbing } \\
\text { dunes; deflation zone }\end{array}$ & $\begin{array}{l}\text { Aeolian processes } \\
\text { (active) }\end{array}$ \\
\hline Sapiatiba Hills & Coastal massifs & $\begin{array}{l}\text { Surface - Single } \\
\text { landform }\end{array}$ & $\begin{array}{l}\text { Massif bordering } \\
\text { Araruama Lagoon }\end{array}$ & $\begin{array}{c}\text { Tectonic processes } \\
\text { (inactive)/ denudational } \\
\text { processes (active) }\end{array}$ \\
\hline $\begin{array}{l}\text { Vermelha } \\
\text { lagoon }\end{array}$ & $\begin{array}{l}\text { Coastal lagoon; } \\
\text { Cultural landscape }\end{array}$ & $\begin{array}{c}\text { Surface - } \\
\text { Geomorphological } \\
\text { System }\end{array}$ & $\begin{array}{l}\text { Double barrier-lagoon } \\
\text { system; Anthropic } \\
\text { landform originated by } \\
\text { the Salinas (areas of } \\
\text { salt production) }\end{array}$ & $\begin{array}{l}\text { Coastal processes; } \\
\text { anthropic processes } \\
\text { (active) }\end{array}$ \\
\hline $\begin{array}{c}\text { Cliffs and } \\
\text { Palaeocliffs of } \\
\text { Rasa Beach }\end{array}$ & Coastal cliffs & $\begin{array}{l}\text { Points - Group of } \\
\text { landforms }\end{array}$ & $\begin{array}{l}\text { Active cliffs; inactive } \\
\text { cliffs (located above } \\
\text { current sea-level) }\end{array}$ & $\begin{array}{l}\text { Marine erosion (active } \\
\text { and inactive); sea level } \\
\text { variations }\end{array}$ \\
\hline $\begin{array}{l}\text { Palaeolagoon of } \\
\text { Reserva Tauá }\end{array}$ & Palaeolagoons & $\begin{array}{l}\text { Surface - Single } \\
\text { landform }\end{array}$ & $\begin{array}{c}\text { Plain composed of } \\
\text { palaeolagoon deposits } \\
\text { (mainly coquines) }\end{array}$ & $\begin{array}{c}\text { Lagoonal sedimentation } \\
\text { (inactive); sea level } \\
\text { variations } \\
\end{array}$ \\
\hline $\begin{array}{l}\text { José Gonçalves } \\
\text { Marine Terrace }\end{array}$ & Marine terraces & $\begin{array}{c}\text { Surface - } \\
\text { Geomorphological } \\
\text { complex }\end{array}$ & Marine terrace; beach & $\begin{array}{l}\text { Coastal processes } \\
\text { (marine deposition) } \\
\text { (active and inactive) }\end{array}$ \\
\hline $\begin{array}{l}\text { Pai Vitório } \\
\text { Point and Stone } \\
\text { Mangrove }\end{array}$ & $\begin{array}{l}\text { Coastal massifs } \\
\text { (aligned ridge) }\end{array}$ & $\begin{array}{c}\text { Surface - } \\
\text { Geomorphological } \\
\text { System } \\
\end{array}$ & $\begin{array}{l}\text { Aligned hills; talus } \\
\text { deposits }\end{array}$ & $\begin{array}{c}\text { Tectonic processes } \\
\text { (inactive); differential } \\
\text { erosion }\end{array}$ \\
\hline $\begin{array}{l}\text { Tartaruga } \\
\text { Beach }\end{array}$ & Erosional beaches & $\begin{array}{l}\text { Line - Single } \\
\text { landform }\end{array}$ & $\begin{array}{l}\text { Beach with high rates } \\
\text { of coastal erosion; } \\
\text { mitigation structures }\end{array}$ & $\begin{array}{l}\text { Marine erosion (active); } \\
\text { anthropic processes }\end{array}$ \\
\hline $\begin{array}{c}\text { Araruama } \\
\text { Lagoon Spits }\end{array}$ & Lagoonal spits & $\begin{array}{l}\text { Surface - Group of } \\
\text { landforms }\end{array}$ & Lagoonal spits & $\begin{array}{l}\text { Lagoonal processes } \\
\text { (intralagoonal waves) } \\
\text { (active) }\end{array}$ \\
\hline $\begin{array}{l}\text { Tucuns Dune } \\
\text { Field }\end{array}$ & $\begin{array}{l}\text { Coastal dunes; } \\
\text { Environmental } \\
\text { impacts }\end{array}$ & $\begin{array}{c}\text { Surface - } \\
\text { Geomorphological } \\
\text { complex }\end{array}$ & $\begin{array}{l}\text { Coastal dunes affected } \\
\text { by urbanisation }\end{array}$ & $\begin{array}{l}\text { Aeolian processes; } \\
\text { anthropic processes } \\
\text { (active) }\end{array}$ \\
\hline $\begin{array}{l}\text { Ferradura } \\
\text { Beach }\end{array}$ & Beaches & $\begin{array}{l}\text { Line - Single } \\
\text { landform }\end{array}$ & $\begin{array}{l}\text { Cove beach with a } \\
\text { well-rounded format } \\
\text { and a narrow bay } \\
\text { entrance }\end{array}$ & Wave diffraction \\
\hline São João Hill & $\begin{array}{l}\text { Alkaline massifs } \\
\text { (hill) }\end{array}$ & $\begin{array}{l}\text { Surface - Single } \\
\text { landform }\end{array}$ & $\begin{array}{l}\text { Hill surrounded by } \\
\text { coastal plain }\end{array}$ & $\begin{array}{c}\text { Tectonic processes } \\
\text { (inactive)/ Denudational } \\
\text { processes (active) }\end{array}$ \\
\hline $\begin{array}{l}\text { Double Barrier- } \\
\text { Lagoon System } \\
\text { of Jacarepiá }\end{array}$ & $\begin{array}{l}\text { Double barrier- } \\
\text { lagoon system }\end{array}$ & $\begin{array}{c}\text { Surface - } \\
\text { Geomorphological } \\
\text { system } \\
\end{array}$ & $\begin{array}{l}\text { Coastal barriers; } \\
\text { lagoons; wetlands; }\end{array}$ & $\begin{array}{c}\text { Coastal processes } \\
\text { (active and inactive)/ } \\
\text { lagoonal sedimentation; }\end{array}$ \\
\hline
\end{tabular}




\begin{tabular}{|c|c|c|c|c|}
\hline & Coastal islands & $\begin{array}{c}\text { foredunes; } \\
\text { intralagoonal spits } \\
\text { Papagaios } \\
\text { Island }\end{array}$ & $\begin{array}{c}\text { Surface }- \\
\text { Georphological } \\
\text { system }\end{array}$ & $\begin{array}{c}\text { aeolian processes } \\
\text { (active); intralagoonal } \\
\text { waves (inactive) }\end{array}$ \\
\hline $\begin{array}{c}\text { Saquarema } \\
\text { denudational forms } \\
\text { within }\end{array}$ & $\begin{array}{c}\text { Tectonic processes } \\
\text { (inactive)/ Marine } \\
\text { erosion on rocky coasts }\end{array}$ \\
\hline $\begin{array}{c}\text { Foredunes and } \\
\text { Secondary } \\
\text { Dunes of } \\
\text { Massambaba }\end{array}$ & Coastal massifs & $\begin{array}{c}\text { Surface - Single } \\
\text { landform }\end{array}$ & $\begin{array}{c}\text { Rocky promontory with } \\
\text { a cave within }\end{array}$ & $\begin{array}{c}\text { Tectonic processes; } \\
\text { marine erosion } \\
\text { (inactive); slope } \\
\text { processes (active) }\end{array}$ \\
\hline
\end{tabular}

\section{Characterisation and quantitative assessment}

$596 \quad$ After the preliminary assessment, all sites were characterised and quantitatively assessed. Fig. 4 displays a map with the location of the sites and the results of the

598 quantitative assessment, highlighting the main values of the site and information 599 concerning the promotion and risks of degradation. Besides the map, Table 10 shows an 600 example of how a geomorphosite is presented in the inventory. Therefore, the inventory 601 consists of a list of geomorphosites with their geomorphological aspects, associated 602 interests and use and management characteristics fully described. 

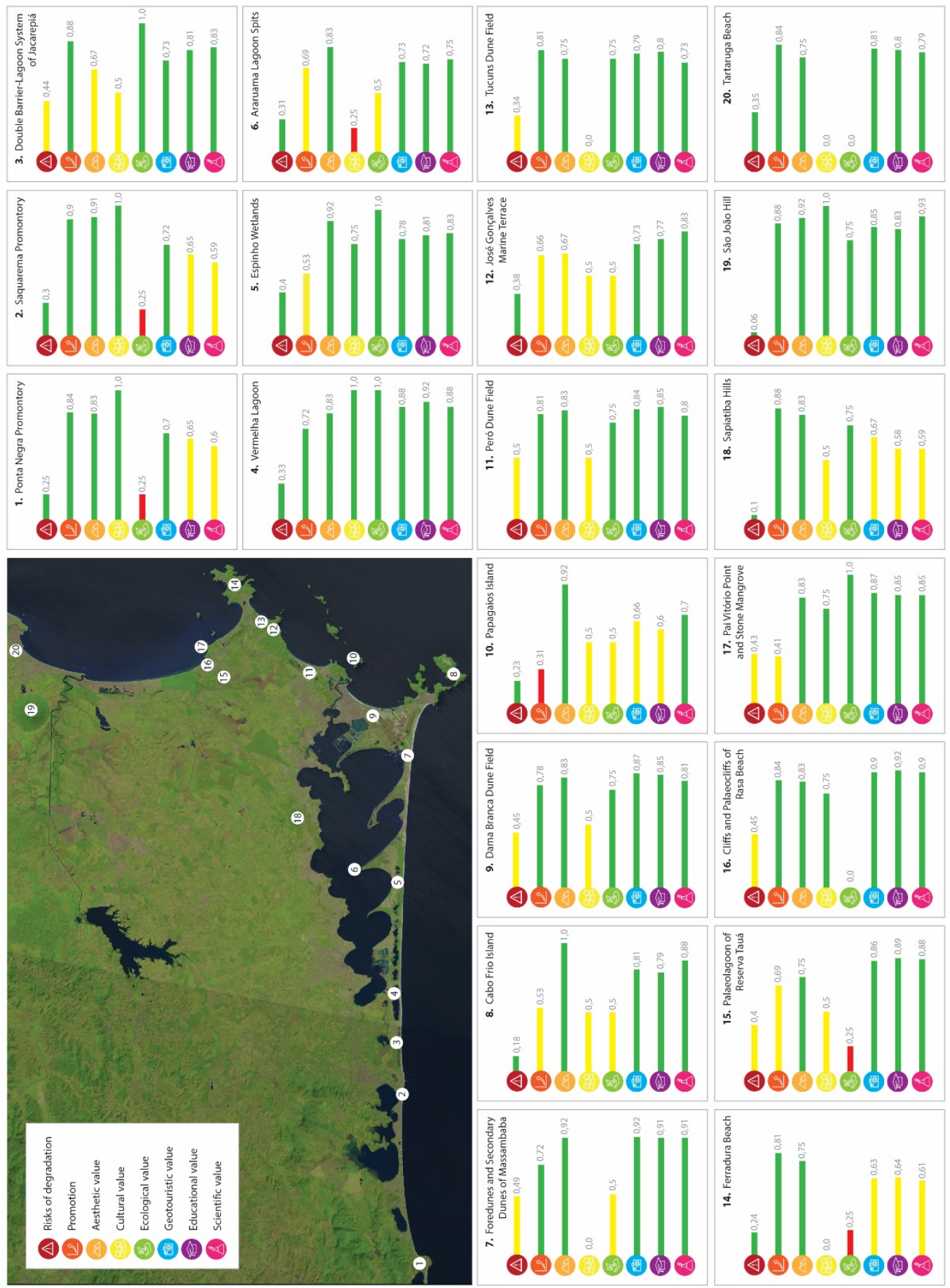

605

Fig. 4: Geomorphosites and quantitative assessment results. The colours of the bars indicate the degree of relevance: green is high (higher than 0,7 ), yellow is medium 
Table 10: Example of geomorphosite fully described in the inventory.

\begin{tabular}{|c|c|c|}
\hline \multirow{4}{*}{ Identification } & Name & Cliffs and Palaeocliffs of Rasa Beach \\
\hline & Location & $\begin{array}{l}\text { Praia Rasa - Armação dos Búzios/ Cabo Frio (State of Rio } \\
\text { de Janeiro): 24K } 7483412194706 \text { (UTM WGS-84) }\end{array}$ \\
\hline & Property & Public \\
\hline & $\begin{array}{l}\text { Eventual use } \\
\text { limitations }\end{array}$ & No limitations \\
\hline \multirow[b]{7}{*}{ Geomorphology } & $\begin{array}{c}\text { Thematic } \\
\text { classification }\end{array}$ & Coastal; Palaeogeographic \\
\hline & Spatial classification & Points - Group of landforms \\
\hline & Area/Size & Punctual occurrences with different dimensions \\
\hline & Altitude & From sea-level to about 35 meters. \\
\hline & Forms & Active and inactive cliffs; abrasion platforms. \\
\hline & Processes & Marine erosion; Sea-level variations. \\
\hline & $\begin{array}{l}\text { Morphogenesis } \\
\text { (chronology) }\end{array}$ & $\begin{array}{l}\text { Cliffs are formed in places of the shoreline where rocks or } \\
\text { sediments impose resistance to wave action, so marine } \\
\text { erosion originates vertical or sub vertical forms. The cliffs in } \\
\text { this geomorphosite are composed of sedimentary rocks from } \\
\text { Barreiras Formation. There is one active cliff and at least four } \\
\text { well represented inactive cliffs, which are related to the } \\
\text { transgressive phase that occurred around } 5100 \text { years BP, } \\
\text { when the sea level was around three meters higher than at } \\
\text { present (Castro et al. 2014). The active cliff is classified as a } \\
\text { Cliff with horizontal shore platform (Davidson-Arnot } 2010 \text { ), } \\
\text { which means that the retreat of the cliff by marine erosion } \\
\text { leaves behind a horizontal platform that is also subject to } \\
\text { erosion, being vertically lowered. This abrasion platform is } \\
\text { composed of debris from the sedimentary rocks, witnessing } \\
\text { the retreat movement of the cliff. }\end{array}$ \\
\hline Associated interests & \multicolumn{2}{|c|}{$\begin{array}{l}\text { Palaeogeographical interest for the sea level variation records; sedimentological } \\
\text { interest for the outcropping of sedimentary rocks from Barreiras Formation; cultural } \\
\text { interest for the presence of a Quilombola traditional community in the area. }\end{array}$} \\
\hline \multirow{9}{*}{$\begin{array}{l}\text { Use and } \\
\text { management }\end{array}$} & Access & $\begin{array}{l}\text { The access is through the Rasa Fishing Colony, in the } \\
\text { entrance of Armação dos Búzios municipality. There is a bus } \\
\text { stop nearby. The site can be visited by disabled people. }\end{array}$ \\
\hline & Safety & There are no major risks. \\
\hline & $\begin{array}{c}\text { Observation } \\
\text { conditions }\end{array}$ & $\begin{array}{l}\text { Both active and inactive cliffs are easily visualised, as well } \\
\text { as the abrasion platform. }\end{array}$ \\
\hline & $\begin{array}{l}\text { Interpretive } \\
\text { potential }\end{array}$ & $\begin{array}{l}\text { The interpretive potential is high since the processes that } \\
\text { originated the inactive cliffs can be observed in the active } \\
\text { cliff. There is a panel of the Caminhos Geologicos } \\
\text { (Portuguese for "geological paths") project explaining the } \\
\text { evolution of the landscape in the area. }\end{array}$ \\
\hline & Site infrastructure & There is a parking area accessible for buses. \\
\hline & $\begin{array}{l}\text { Regional touristic } \\
\text { infrastructure }\end{array}$ & $\begin{array}{l}\text { The municipality of Armação dos Búzios is one of the major } \\
\text { touristic destinations of Brazil, presenting a well-developed } \\
\text { infrastructure for visitors. }\end{array}$ \\
\hline & $\begin{array}{l}\text { Integrity and } \\
\text { protection status }\end{array}$ & $\begin{array}{l}\text { The site is well conserved. There is no legal protection, but } \\
\text { the traditional communities that inhabit the area contribute to } \\
\text { the protection. }\end{array}$ \\
\hline & Fragility & $\begin{array}{l}\text { The process of marine erosion is constantly affecting the } \\
\text { active cliff. However, its rate is too low to be considered as a } \\
\text { factor enhancing the fragility of the site. }\end{array}$ \\
\hline & Vulnerability & $\begin{array}{l}\text { The high rate of urban growth is the main factor of anthropic } \\
\text { vulnerability. There are houses being built above the } \\
\text { palaeocliffs and the continuation of this process could impose } \\
\text { damages and/or affect the scientific, educational and } \\
\text { geotouristic uses. The palaeocliffs are subject to mass } \\
\text { movements, enhancing the natural vulnerability. }\end{array}$ \\
\hline
\end{tabular}




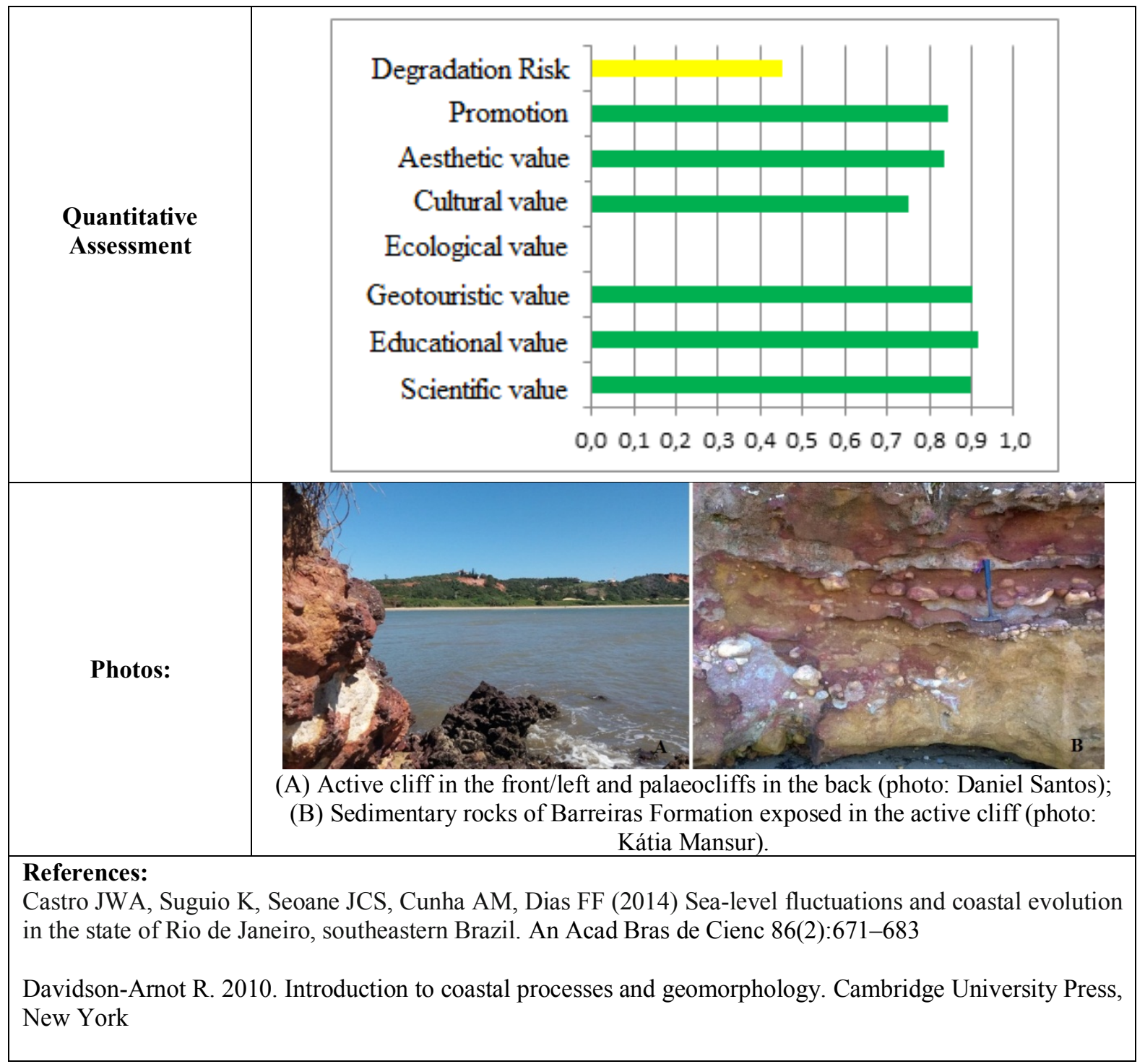

615

The quantitative results displayed on Fig. 4 allow a quick identification of the main values of each geomorphosite, as well as its suitability for the promotion of its use and its risk of degradation. It is important to highlight that this value only indicates a situation and it is not enough to provide a diagnosis. This is why it is important to present the quantitative assessment together with the characterisation, allowing the understanding of the achieved values and eventually the proposition of actions to enhance the potential of use and to guarantee the conservation of the sites.

For instance, the Cliffs and Palaeocliffs of Rasa Beach geomorphosite (Table 10) shows high scores for most values (except ecological value, which is zero). Thus, the site has a good use potential and also cultural relevance. Besides that, the promotion parameter is also high, showing that the site can be considered ready to be used. However, the risk of degradation is medium. The value itself does not say a lot, it only highlights that there could be problems. By reading the description, it is clear that the problem is related to the high rates of urban growth in the region, enhancing the anthropic vulnerability of the geomorphosite. Therefore, there are no problems concerning the 
631

632

633

634

635

636

637

638

639

640

641

642

643

644

645

646

647

648

649

650

651

652

653

654

655

656

657

658

659

660

661

662

663

664

665 visits, since the site is not vulnerable to this type of activity, but measures should be taken to prevent damages related to urban growth.

Another interesting example is the Espinho Wetlands geomorphosite, which is marked by high values and low degradation risk, which is a very good situation for scientific, educational and geotouristic uses. However, the promotion parameter is medium, showing that there are difficulties for the use. Again, the reasons for the lower score are provided in the characterisation (Table 11), which shows that the problem is related to the access and the safety. Therefore, in order to exploit the use potentials of the site, solving these issues is crucial.

Table 11: Description of Access and Safety of the Espinho Wetlands geomorphosite, showing the problems for the promotion of the site.

\begin{tabular}{|c|l|}
\hline \multirow{2}{*}{ Access } & $\begin{array}{l}\text { The site is accessed through Figueira Road (RJ 102), in the } \\
\text { proximities of Caiçara village. There are no signs indicating } \\
\text { the existence of the geomorphosite, neither a parking area nor } \\
\text { bus stop nearby. A walk through a trail amidst thorn bush is } \\
\text { necessary to reach the site, making it difficult for disabled } \\
\text { visitors. (Espinho stands for thorn in Portuguese) }\end{array}$ \\
\hline Safety & $\begin{array}{l}\text { The absence of a parking area enhances the risks for visitors } \\
\text { because the site is located in a high speed road. The site itself } \\
\text { does not present risks. }\end{array}$ \\
\hline
\end{tabular}

It is possible to observe that most of the geomorphosites achieved high scores for the scientific, educational and geotouristic values. Only five did not achieve high scores in all of them. Some sites, such as Cabo Frio Island and São João Hill were exceptional, with high values in all of the parameters. This fact can be explained by the preliminary assessment that guaranteed that only relevant sites were selected to be in the inventory; so, logically, it does not have sites with low scores.

It is also possible to observe that most of the sites have low risk of degradation. Eight of them were considered with medium risk and none with high risk. The reason for this fact is that the geomorphosites in this inventory usually do not present significant fragility and the anthropic vulnerability is related to high impact actions, such as urban growth. Lower impact activities, such as visiting, do not represent a significant rise for the vulnerability.

\section{DISCUSSION}

The importance of geosite inventories as a tool for environmental management have been highlighted in many works (e.g Fuertes-Gutiérrez and Fernandez-Martínez 2010, 2012; Fassoulas et al. 2012; Poiraud et al. 2016; Santos-González and MarcoReguero 2019; Selmi et al. 2019). Land use management in a geoconservation context requires tools that can be easily interpreted by managers which are not always experts in geosciences (Coratza and Regolini-Bissig 2009; Fuertes-Gutiérrez and FernandezMartínez 2012). The intention of the proposed method was to develop an inventory of geomorphosites to be used as a tool for managers, considering their values, potential uses, 
promotion and risks of degradation. It was achieved through the integrated quantitative results (easily interpreted) and a full "diagnosis" of the site. Therefore, more than simply ranking, the quantitative assessment proposed here is intended to support the identification of management priorities at each site. The method does not intend to create rankings because it could lead to the dangerous conclusion that the sites at the bottom of the ranking are not so important. All sites selected in the preliminary assessment are important and they are different from each other (from massifs related to tectonic events to coastal barriers related to sea level variations). So, the outcomes of the quantitative assessment intend to provide information about each site and help in the establishment of priorities and guidelines for the sites themselves, without creating comparisons among them.

The work of Mucivuna et al. (2019) highlighted a very important issue: there are already many published methods for creating inventories and most of them only have a small impact on the scientific community. Many methods were not reproduced by other research and some were successfully reproduced in other contexts (e.g Tavares et al. 2020, who applied the method presented by Brilha 2016 in Brazil). So, what is the need of proposing new methods if there are already too many and some have proven to be capable of being reproduced? The answer is simple. Despite the existence of dozens of methods, most were created for specific situations and there are still discussions to be performed in order to develop a more universally accepted method. The aim of this article is not at all proposing this universal method, but to bring the debate forward in order to contribute in this context of methodological development.

The application of the method in the southeast coast of Rio de Janeiro State allowed the identification of geomorphosites in all geomorphological contexts, which was done during the Preliminary Assessment. This is a crucial step because an inventory must present the complete geomorphological setting of the area, allowing the understanding of which units are present and the morphogenetic history of the area (Sellier 2016; Reynard et al. 2016). There are geomorphosites representing coastal massifs related to tectonic movements between the Palaeocene and Pliocene, alkaline massifs related to magmatic events during the Eocene, several features related to sea-level variations during the Quaternary, aeolian features and cultural landscapes. Therefore, by studying the geomorphosites in the inventory, it is possible to have a complete overview of the geomorphological setting of the region.

As highlighted by Lima et al. (2010), methods for inventorying geosites must have clear aims. In fact, the aim of the inventory defines what type of parameters will be assessed. However, it is clear that works focused on the scientific value (e.g Coratza and Giusti 2005;), educational value (e.g Bollati et al. 2012) and touristic value (e.g Pralong 2005) present similar parameters for the assessment, highlighting that these values are actually strongly related with each other. For instance, the high scientific value of a site may enhance the educational value, since it is usually interesting to visit such sites with students. The same can be said about the geotouristic value, since a site can become interesting for visitors due to its scientific relevance. However, using exactly the same method to assess three different values would be wrong and could create incoherencies like including the aesthetic value as a part of the scientific value or the scientific knowledge as a part of the geotouristic value. Even when the same parameter is used, 
711

712

713

714

715

716

717

718

719

720

721

722

723

724

725

726

727

728

729

730

731

732

733

734

735

736

737

738

739

740

741

742

743

744

745

746

747

748

749

750

751

752

753

they do not have the same weight depending on the value. For that reason, the proposed method used almost the same parameters for the three values, but with a weighting scheme (Table 3) to modify the results. By doing so, an integrated result was achieved without using too many different parameters, presenting the scientific, educational and geotouristic values and considering that these values represent the use potential of the site.

The method uses weighting to assess the value and the risks of degradation in order to address the fact that some parameters are more important than others, depending on what is being assessed. The values assessed are intangible, since they are related to the human perception, being subjective. One of the main efforts in inventory and assessment methods is reducing this subjectivity, but it is crucial to emphasise that it is impossible to eliminate it. Therefore, the most important is to be transparent in how the criteria are being used and why some criteria have different weight. It is also crucial to highlight that the weighting was essential to differentiate the assessment of the scientific, educational and geotouristic values, since they share most of the parameters.

Santos et al. (2019) highlighted the influence of the specificities of geomorphosites in assessment procedures and there were also taken into account in the development of the method presented here. Concerning the imbrication of temporal scales, the palaeogeographical value was considered part of the representativeness of the sites instead of being assessed separately as in some other methods (e.g Bollati et al. 2012; Reynard et al. 2016). A site that has palaeogeographic value was considered to be representative of some periods of Earth's history in the studied area, so this parameter should be part of the representativeness. This modification was mainly proposed because, when assessed separately, sites with palaeogeographic value tended to have much higher scores than sites showing only active processes, creating an imbalance. By including this parameter as part of the representativeness, these sites still have higher scores, but the disparities were smaller.

The work of Santos et al. (2019) also pointed the importance of the specificities, especially the spatial scale and dynamic dimension, in the assessment of risks of degradation. In this sense, the use of the method proposed by García-Ortiz et al. (2014) proved to be a solution because the parameters used were sufficient to cover all situations where the specificities imposed the need of different approaches. The importance of using this method is due to the fact that other quantitative methods, such as that of Brilha (2016), use, for instance, the distance of the site to areas or activities with potential to cause damage as parameter. Because of the complexity related to the spatial scale and the dynamic dimension of geomorphosites, such parameter was often difficult to apply. Nonetheless, other parameters used by Brilha (2016) were included in the proposed method: the accessibility and the legal protection, which was modified with the inclusion of indirect protection. By applying the concepts of fragility and vulnerability, it was also possible to distinguish between processes directly related to the site and external processes. This is essential for management because, as stated by García-Ortiz et al. (2014), natural processes enhancing the fragility of a site should not be stopped or mitigated, since the natural rhythm of degradation of the site must be respected. 
Including the additional values (ecological, cultural and aesthetic) as parameters to assess the scientific, educational and geotouristic values is also an important point of discussion. First, many geomorphosites clearly represent the relationship between geomorphology and biological elements and connecting geodiversity and biodiversity is crucial to strengthen nature conservation actions (Matthews 2014). Also, many methods include the ecological value as part of the scientific value (e.g Panizza 2001; Bollati et al. 2015); for these reasons the ecological value was included in the proposed method. Second, considering cultural geomorphology as an important field of research (see Panizza and Piacente 2008; Reynard and Giusti 2018), it seemed incorrect to only include the cultural value as additional. The links between culture and geomorphology must be emphasised in scientific and educational contexts. Besides that, it may be an important factor to enhance geotourism (Pralong 2005; Coratza et al. 2016). Third, the aesthetic value was excluded from the assessment of scientific value, but included in the educational and geotouristic values. For the educational value, the aesthetic dimension of geomorphosites is a factor that helps to attract the attention, which is essential for educational activities. For the geotouristic value, the aesthetic dimension is usually the most important factor to attract tourists. Therefore, these so-called additional values were included in the assessment of the use values.

Concerning the aesthetic value, the method proposed here considers that it is not possible to quantify the "beauty" of a site; so the parameters used are linked to the possibility of attracting visitors due to the aesthetic value. The difficulty related to the subjectivity in the assessment of the aesthetic value was recognized in many previous works. In order to tackle this issue, authors have been proposing different ways to assess this value. Reynard et al. (2016), for instance, include the existence of viewpoints and parameters to directly assess the aesthetics of the site (colour contrast, vertical development and space structuration), while others, such as Brilha (2016) do not assess it directly, using the touristic use of the site as parameter. The proposed method does not assess the aesthetics directly, but considers visualization conditions, similarly to Reynard et al. (2016); the conservation, since degradation represents an alteration of the aesthetics of the site; and, instead of using the touristic use (as in Brilha 2016), the potential to attract visitors due to the aesthetic dimension is used. It may be more subjective than the touristic use, but it is common to have sites with great scenic beauty which are not touristic destinations. It would not be correct to give a low aesthetic value to such sites.

Clearly differentiating values from use and management characteristics is one of the most important issues when assessing geosites, especially quantitatively. Reynard et al. (2016) stated that characteristics of use and management are not intrinsic values of the sites and, for that reason, are not quantitatively assessed in their method, being only described. However, other methods (e.g Serrano and González-Trueba 2005; Pereira and Pereira 2010; Brilha 2016) quantitatively assess use and management parameters, which is interesting because, despite not being values, the quantitative assessment also constitutes a tool for management as it provides a simple and easily interpreted result, allowing a quick identification of priorities, for instance.

Brilha (2016) uses parameters of use and management to assess the potential educational and touristic uses of geosites. Although this makes sense, since geosites must have good conditions to receive visitors, it seems a problem in the assessment of several 
sites which are geomorphologically interesting but have problems related to their management. By separating the intrinsic values of the sites from the use and management characteristics, it is possible to identify sites that need attention in order to become a visiting place. In other words, it was more interesting to identify the sites that could become interesting destinations than simply saying that they have low educational or geotouristic use potential, which could, for instance, weaken protective measures.

Finally, it is important to emphasise the importance of the Preliminary Assessment for the selection of relevant geomorphosites in the inventory, avoiding time spent performing complete evaluations of sites that, in the end, would never yield high values and, therefore, use potentials. The results showed that none of the quantitatively assessed sites presented low values and the Preliminary Assessment is the main responsible for that. The proposed method was mainly inspired by the works of Sellier (2016) and Reynard et al. (2016) in what concerns the complete understanding of the geomorphological setting of the area and by Pereira and Pereira (2010) for the assessment of basic, additional, and use and management parameters. This step was crucial to make the whole process of inventorying more efficient.

\section{CONCLUSIONS}

The main result of this research consists of the inventory of geomorphosites with full description of their geomorphological and use and management aspects, and the quantitative assessment of their values, promotion potential and risk of degradation. This inventory is intended to be a tool for territorial management, supporting actions of geoconservation and sustainable use of the geomorphosites.

Identifying and evaluating geosites is a basic step in geoconservation strategies and, within the context of abiotic ecosystem services, is a valuable tool to provide a series of knowledge services, ranging from understanding Earth History to teaching society as a whole about elements and processes that directly affect their lives. It is especially important considering the negative effects of natural disasters or the eventual consequences of climatic change. Therefore, geosites must be protected and sustainably used for the benefit of humanity.

Besides the knowledge services, geosites may also be used for sustainable economic development through activities such as geotourism. Inventories are basic tools for managers to identify geosites with high use potentials but still need actions to improve the accessibility or safety issues, for instance. It also helps in the identification of sites that need protective measures. By integrating the characterisation and the quantitative assessment, it was possible to achieve this aim, since the final product provides a diagnosis of the site as well as an easily interpreted quantitative result.

The proposed method differs from previous ones in several aspects. It assesses the scientific, educational and geotouristic values as representative of the use potentials of the sites. The assessment of these values is done through similar parameters, using weights to differentiate them in the evaluation, resulting in an integrated outcome without the need of using too many parameters. It integrates the characterisation and the quantification in order to provide a complete and more easily interpreted product. 
842

843

Therefore, the quantification is not used to create rankings, but to display the values and the use and management characteristics of each site. The whole procedure considers the specificities of geomorphosites, which is essential to assess the values and risks of degradation without incoherencies or misjudgements. The additional values are used as parameters to assess the use values, which highlights the links between them. Concerning the aesthetic value, which is one of the most difficult to assess due to the subjectivity, the proposed method focuses the assessment not in the quantification of how beautiful the site is, but in the capacity to use the aesthetic dimension to attract visitors and call their attention. Finally, it is crucial to highlight the transparency of the method, allowing the reproduction and critical analysis of each parameter.

Therefore, this work had the aim of proposing a method inserted in the actual context of methodological development, contributing in the discussion and advancing in the achievement of more universally applied methods. Geoconservation has been growing in importance in the last decades and reliable and transparent methods are essential in order to be effectively included in the environmental management agenda.

\section{ACKNOWLEDGEMENTS}

This work was funded by the Coordination for the Improvement of Higher Personnel (CAPES - Brazilian government). We thank Prof. Dr. Cátia Fernandes Barbosa for the support in the fieldwork, Beatriz Vianna Reis for producing Figure 4 and Carolina Gomes for the English review. We are also grateful for the comments of two anonymous reviewers who significantly contributed to improve the article.

\section{REFERENCES}

Ashton A, Murray AB, Arnoult O (2001) Formation of coastline features by large-scale instabilities induced by high-angle waves. Nature 414:296-300. https://doi.org/ $10.1038 / 35104541$

Asmus HE, Ferrari AL (1978) Hipótese sobre a causa do tectonismo cenozoico na região sudeste do Brasil. Série Projeto REMAC 4:75-88

Barbiére E. 1975. Ritmo climático e extração de sal em Cabo Frio. Revista Brasileira de Geografia 37(4):23-109 (in Portuguese)

Beraaouz M, Macadam J, Bouchaou L, Ikenne M, Ernst R, Tagma T, Masrour M (2019) An inventory of geoheritage sites in the Draa Valley (Morocco): a contribution to promotion of geotourism and sustainable development. Geoheritage 11(2):241-255. https://doi.org/10.1007/s12371-017-0256-x

Bollati I, Leonelli G, Vezzola L, Pelfini M (2015) The role of ecological value in geomorphosite assessment for the debris-covered Miage Glacier (Western Italian Alps) based on a review of 2.5 centuries of scientific study. Geoheritage 7(2):119-135. https://doi.org/10.1007/s12371-014-0111-2 
881 Bollati I, Pelfini M, Pellegrini L (2012) A geomorphosites selection method for 882 educational purposes: a case study in Trebbia Valley (Emilia Romagna, Italy). Geogr Fis 883 Dinam Quat 35(1):23-35. https://doi.org/10.4461/GFDQ.2012.35.3

884 Bollati I, Smiraglia C, Pelfini M (2013) Assessment and selection of geomorphosites and 885 trails in the Miage Glacier Area (Western Italian Alps) Environ Manage 51:951-967. 886 https://doi.org/10.1007/s00267-012-9995-2

887 Brilha J (2016) Inventory and quantitative assessment of geosites and geodiversity sites: 888 A review. Geoheritage 8(2):119-134. https://doi.org/10.1007/s12371-014-0139-3

889 Brilha J (2017) Trends and challenges for geoconservation. Geophysical Research 890 Abstracts 19:8626

891 Brilha J (2018) Geoheritage: inventories and evaluation. In: Reynard E, Brilha J (eds) 892 Geoheritage: Assessment, Protection and Management. Elsevier, Amsterdam, pp 69-86

893 Brilha J, Gray M, Pereira DI, Pereira P (2018) Geodiversity: An integrative review as a 894 contribution to the sustainable management of the whole of nature. Environ Sci Policy 895 86:19-28. https://doi.org/10.1016/j.envsci.2018.05.001

896 Brocx M, Semeniuk V (2007) Geoheritage and geoconservation - history, definition, 897 scope and scale. J Roy Soc West Aust 90:53-87

898 Bruschi VM, Cendrero A (2005) Geosite evaluation: can we measure intangible values? 899 Il Quaternario 18(1):293-306

900 Bruschi VM, Cendrero A, Albertos JAC (2011) A statistical approach to the validation 901 and optimization of geoheritage assessment procedures. Geoheritage 3:131-149. 902 https://doi.org/10.1007/s12371-011-0038-9

903 Castro JWA, Suguio K, Seoane JCS, Cunha AM, Dias FF (2014) Sea-level fluctuations 904 and coastal evolution in the state of Rio de Janeiro, southeastern Brazil. An Acad Bras de 905 Cienc 86(2):671-683. https://doi.org/ 10.1590/0001-3765201420140007

906 Clivaz M, Reynard E (2018) How to integrate invisible geomorphosites in an inventory: 907 a case study in the Rhone River valley (Switzerland). Geoheritage 10(4):527-541. $908 \mathrm{https}: / / 10.1007 / \mathrm{s} 12371-017-0222-7$

909 Comănescu L, Nedelea A, Dobre R (2012) The evaluation of geomorphosites from the 910 Ponoare Protected Area. Forum Geografic 11(1):54-61. https://doi.org/10.5775/fg.2067$911 \quad 4635.2012 .037 . \mathrm{i}$

912 Comer P, Pressey RL, Hunter ML, Schloss CA, Buttrick SC, Heller NE, Tirpak JM, Faith 913 DP, Cross MS, Shaffer ML (2015) Incorporating geodiversity into conservation 914 decisions. Conserv Biol 29(3):692-701. https://doi.org/10.1111/cobi.12508

915 Coratza P, Giusti C (2005) Methodological proposal for the assessment of the scientific 916 quality of geomorphosites. Il Quaternario 18(1):307-313

917 Coratza P, Regolini-Bissig G (2009.) Methods for mapping geomorphosites. In: Reynard 918 E, Coratza P, Regolini-Bissig G (eds) Geomorphosites. Pfeil, München, pp 89-103 
919 Coratza P, De Waele (2012) Geomorphosites and Natural Hazards: Teaching the 920 Importance of Geomorphology in Society. Geoheritage 4(3):195-203. 921 https://doi.org/10.1007/s12371-012-0058-0

922 Coratza P, Hobléa F (2018) The specificities of geomorphological heritage. In: Reynard 923 E, Brilha J (eds) Geoheritage: Assessment, Protection and Management. Elsevier, 924 Amsterdam, pp 87-106

925 Coratza P, Gauci R, Schembri J, Soldati M, Tonelli D (2016) Bridging natural and cultural 926 values of sites with outstanding scenery: Evidence from Gozo, Maltese Islands. 927 Geoheritage 8(1):91-103. https://doi.org/10.1007/s12371-015-0167-7

928 Daily GC (1997) Introduction: what are ecosystem services? In: Daily GC (ed) Nature's 929 services: Societal dependence on natural ecosystems. Island Press, Washington DC, pp $930 \quad 1-10$

931 Davidson-Arnot R. 2010. Introduction to coastal processes and geomorphology. 932 Cambridge University Press, New York

933 Debenay JP, Geslin E, Eickler BB, Duleba W, Sylvestre F, Eichler P (2001) Foraminiferal 934 assemblages in a hypersaline lagoon, Araruama (R.J.) Brazil. J Foramin Res 31(2):133$935 \quad 151$

936 Dowling RK (2013) Global geotourism - An emerging form of sustainable tourism. 937 Czech J Tour 2(2):59-79. https://doi.org/10.2478/cjot-2013-0004

938 Fassoulas C, Mouriki D, Dimitriou-Nikolakis P, Ilipoulos G (2012) Quantitative 939 assessment of geotope as an effective tool for geoheritage management. Geoheritage 940 4(3):177-193. https://doi.org/10.1007/s12371-011-0046-9

941 Farsani NT, Coelho C, Costa C (2011) Geotourism and geoparks as novel strategies for 942 socio-economic development in rural areas. Int $\mathrm{J}$ Tourism Res 13:68-81. 943 https://doi.org/10.1002/jtr.800

944 Fernandez GB, Pereira TG, Rocha B (2009) Coastal dunes along Rio de Janeiro coast: 945 Evolution and management. J Coast Res 56:307-311

946 Ferreira ARG, Lobo HAS, Perinotto JAJ (2019) Inventory and quantification of geosites 947 in the State Tourist Park of Alto Ribeira (PETAR, São Paulo State, Brazil). Geoheritage 948 11(3):783-792. https://doi.org/10.1007/s12371-018-0331-y

949 Fuertes-Gutiérrez I, Fernández-Martínez E (2010) Geosites inventory in the Leon 950 Province (Northwestern Spain): a tool to introduce geoheritage into regional 951 environmental management. Geoheritage 2:57-75. https://doi.org/10.1007/s12371-010952 0012-y

953 Fuertes-Gutiérrez I, Fernández-Martínez E (2012) Mapping geosites for geoheritage 954 management: a methodological proposal for the regional park of Picos de Europa (León, 955 Spain). Environ Manage 50(5):789-806. https10.1007/s00267-012-9915-5

956 Garcia et al. (2018) The inventory of geological heritage of the State of São Paulo, Brazil: 957 Methodological basis, results and perspectives. Geoheritage 10(2): 239-258. 958 https://doi.org/10.1007/s12371-016-0215-y 
959 García-Ortiz E, Fuertes-Gutiérrez I, Fernández-Martínez E (2014) Concepts and 960 terminology for the risk of degradation of geological heritage sites: fragility and natural 961 vulnerability, a case study. Proc Geol Assoc 125:463-479. 962 https://doi.org/10.1016/j.pgeola.2014.06.003

963 Gordon JE, Barron HF, Hansom JD, Thomas MF (2012) Engaging with geodiversity 964 why it matters. Proc Geol Assoc 123(1):1-6 https://doi.org/10.1016/j.pgeola.2011.08.002

965 Goudie AS (2002) Aesthetics and relevance in geomorphological outreach. 966 Geomorphology 47(2):245-249. https://doi.org/10.1016/S0169-555X(02)00090-9

967 Grandgirard V (1999) L'évaluation des Géotopes. Geologia inssubrica 4(1):59-66

968 Gray M (2011) Other nature: Geodiversity and geosystem services. Environ Conserv 969 38:271-274. https://doi.org/10.1017/SO376892911000117

970 Gray M (2013) Geodiversity: valuing and conserving abiotic nature. 2nd edn. Wiley971 Blackwell, Chichester

972 Gray M, Gordon JE, Brown EJ (2013) Geodiversity and the ecosystem approach: the 973 contribution of geoscience in delivering integrated environmental management. Proc 974 Geol Assoc 124(4):659-673. https://doi.org/10.1016/j.pgeola.2013.01.003

975 Henriques MH, Pena dos Reis R, Brilha J, Mota T (2011) Geoconservation as an 976 emerging geoscience. Geoheritage 3:117-128. https://doi.org/10.1007/s12371-011-00399778

978 Hjort J, Gordon JE, Gray M, Hunter Jr ML (2015) Why geodiversity matters when 979 valuing nature's stage. Conserv Biol 29(3):630-639. https://doi.org/10.1111/cobi.12510

980 Hose TA (2012) 3 G's for modern geotourism. Geoheritage 4:7-24. 981 https://doi.org/10.1007/s12371-011-0052-y

982 Khalaf EDAH, Wahed MA, Maged A, Mokhtar H (2019) Volcanic geosites and their 983 geoheritage values preserved in Monogenetic Neogene Volcanic Field, Bahariya 984 Depression, Western Desert, Egypt: Implication for climatic change-controlling volcanic 985 eruption. Geoheritage 11(3):855-873. https://doi.org/10.1007/s12371-018-0336-6

986 Kubalíková L (2013) Geomorphosite assessment for geotourism purposes. Czech Journal 987 of Tourism 2(2):80-104. https://doi.org/10.2478/cjot-2013-0005

988 Lima FF, Brilha J, Salamuni E (2010) Inventory of geological heritage in large territories: 989 a methodological proposal applied to Brazil. Geoheritage 2(3):91-99. 990 https://doi.org/10.1007/s12371-010-0014-9

991 Martin L, Suguio K, Flexor JM, Dominguez JML, Bittencourt ACSP (1996) Quaternary 992 sea-level history and variation in dynamics along the Central Brazilian Coast: 993 Consequences on coastal plain construction. An Acad Bras Cienc 68(3):303-354

994 Matthews TJ (2014) Integrating geoconservation and biodiversity conservation: 995 theoretical foundations and conservation recommendations in a European Union context. 996 Geoheritage 6(1):57-70. https://doi.org/10.1007/s12371-013-0092-6 
997 Megerssa L, Rapprich V, Novotný R, Verner K, Erban V, Legesse F, Manaye M (2019) 998 Inventory of key geosites in the Butajira Volcanic Field: Perspective for the first geopark 999 in Ethiopia. Geoheritage 11(4):1643-1653. https:doi.org/ 10.1007/s12371-019-00393-y

1000 Migón P, Pijet-Migón E (2017) Viewpoint geosites - values, conservation and 1001 management issues. Proc Geol Assoc 128(4):511-522. https://doi.org/ 1002 10.1016/j.pgeola.2017.05.007

1003 Millennium Ecosystem Services (2005) Ecosystems and human well-being: synthesis. 1004 Island Press, Washington DC

1005 Mucivuna VC, Reynard E, Garcia MGM (2019) Geomorphosites assessment methods: 1006 comparative analysis and typology. Geoheritage 11(4):1799-1815. 1007 https://doi.org/10.1007/s12371-019-00394-X

1008 Newsome D, Dowling R (2010) Setting an ageda for geotourism. In: Newsome D, 1009 Dowling R (eds) Geotourism: The tourism of geology and landscape. Good Fellow 1010 Publishers, Oxford

1011 Panizza M (2001) Geomorphosites: concepts, methods and example of geomorphological 1012 survey. Chin Sci Bull 46:4-5. https://doi.org/10.1007/BF03187227

1013 Panizza M, Piacente S (2008) Geomorphology and cultural heritage in coastal 1014 environments. Geogr Fis Din Quat 31:205-210.

1015 Parks KE, Mulligan M (2010) On the relationship between a resource based measure of 1016 geodiversity and a broad scale biodiversity patterns. Biodivers Conserv 19:2751-2766. 1017 https://doi.org/10.1007/s10531 -010-9876-z

1018 Pelfini M, Bollati I (2014) Landforms and geomorphosites ongoing changes: Concepts 1019 and implications for geoheritage promotion. Quaest Geogr 33(1):131-143. 1020 https://doi.org/10.2478/quageo-2014-0009

1021 Pellitero R, Manosso FC, Serrano E (2014) Mid- and Large-Scale Geodiversity 1022 Calculation in Fuentes-Carrionas (NW Spain) and Serra do Cadeado (Paraná, Brazil): 1023 Methodology and Application for Land Management. Geografiska Annaler: Series A, 1024 Physical Geography 97(2):19-235. https://doi.org/10.1111/geoa.12057

1025 Pereira DI, Pereira P, Brilha J, Santos L (2013) Geodiversity Assessment of Parana State 1026 (Brazil): An Innovative Approach. Environ Manage 52:541-552. 1027 https://doi.org/10.1007/s00267-013-0100-2

1028 Pereira P, Pereira D, Caetano Alves MI (2007) Geomorphosite assessment in Montesinho 1029 Natural Park (Portugal). Geogr Helv 62(3):159-168. https://doi.org/10.5194/gh-62-15910302007

1031 Pereira P, Pereira D (2010) Methodological guidelines for geomorphosite assessment. 1032 Géomorphol Relief Process Environ 2:215-222. 1033 https://doi.org/10.4000/geomorphologie.7942

1034 Perret A (2014) Géopatrimoines des trois Chablais: identification et valorisation des 1035 témoins glaciaires. Ph.D. thesis, University of Lausanne and University of Grenoble 1036 Alpes (in French) 
1037 Phuong TH, Duong NT, Hai TQH, Dong BV (2017) Evaluation of the geological heritage 1038 of the Dray Nur and Dray Sap waterfalls in the Central Highlands of Vietnam. 1039 Geoheritage 9(1):49-57. https://doi.org/10.1007/s12371-016-0176-1

1040 Poiraud A, Chevalier M, Claeyssen B, Biron PE, Joly B (2016) From geoheritage 1041 inventory to territorial planning tool in the Vercors massif (French Apls): Contribution of 1042 statistical and expert cross approaches. Appl Geogr 71:69-82. https://doi.org/ $1043 \quad 10.1016 /$ j.apgeog.2016.04.012

1044 Pralong JP (2005) A method for assessing tourist potential and use of geomorphological 1045 sites. Géomorphol Relief Process Environ 3:189-195. 1046 https://doi.org/10.4000/geomorphologie.350

1047 Reynard E (2009) The assessment of geomorphosites. In: Reynard E, Coratza P, Regolini1048 Bissig G (eds) Geomorphosites. Pfeil, Munchen, pp 63-71

1049 Reynard E, Brilha J (eds) (2018) Geoheritage: Assessment, Protection and Management. 1050 Elsevier, Amsterdam

1051 Reynard E, Giusti C (2018) The landscape and the cultural value of geoheritage. In: 1052 Reynard E, Brilha J (eds) Geoheritage: Assessment, protection and management. 1053 Elsevier, Amsterdam, pp 147-166

1054 Reynard E, Perret A, Bussard J, Grangier L, Martin S (2016) Integrated approach for the 1055 inventory and management of geomorphological heritage at the regional scale. 1056 Geoheritage 8(1):43-60. https://doi.org/10.1007/s12371-015-0153-0

1057 Rodrigues J (2013) Geosite management in Geopark Naturtejo da Meseta Meridional, 1058 Portugal: geomorphological viewpoints. In: Hobléa F, Cayla N, Reynard E (eds) 1059 Managing geosites in protected areas. Collection Edytem, 15, pp 65-70

1060 Santos DS, Mansur KL, Gonçalves JB, Arruda Junior ER, Manosso FC (2017) 1061 Quantitative assessment of geodiversity and urban growth impacts in Armação dos 1062 Búzios, Rio de Janeiro, Brazil. Appl Geogr 85:184-195. 1063 https://doi.org/10.1016/j.apgeog.2017.03.009

1064 Santos DS, Reynard E, Mansur KL, Seoane JCS (2019) The specificities of 1065 geomorphosites and their influence on assessment procedures: a comparative analysis. 1066 Geoheritage 11(4):2045-2064. https://doi.org/ 10.1007/s12371-019-00411-z

1067 Santos-González J, Marcos-Reguero A (2019) Applying the geological heritage in land 1068 management: cartography and management proposals of geosites in Burgos Province 1069 (Spain). Geoheritage 11(2):485-500. https://doi.org/10.1007/s12371-018-0301-4

1070 Santos WFS, Carvalho IS, Brilha JB, Leonardi G (2016) Inventory and assessment of 1071 palaeontological sites in the Sousa Basin (Paraíba, Brazil): Preliminary study to evaluate 1072 the potential of the area to become a geopark. Geoheritage 8(4):315-332. 1073 https://doi.org/10.1007/s12371-015-0165-9

1074 Schmitt RS, Trouw R, Van Schmus WR, Armstrong R, Stanton NSG (2016) The tectonic 1075 significance of the Cabo Frio Tectonic Domain in the SE Brazilian margin: a 
1076 Paleoproterozoic through Cretaceous saga of reworked continental margin. Braz J Geol 1077 46(1):37-66 https://doi.org/10.1590/2317-4889201620150025

1078 Sellier D. 2016. A deductive method for the selection of geomorphosites: Application to 1079 Mont Ventoux (Provence, France). Geoheritage 8(1):15-29. 1080 https://doi.org/10.1007/s12371-015-0144-1

1081 Serrano E, González Trueba JJ (2005) Assessment of geomorphosites in natural protected 1082 areas: the Picos de Europa National Park (Spain). Géomorphol Relief Process Environ 1083 3:197-208. https://doi.org/10.4000/geomorphologie.364

1084 Silva-García JT, Cruz-Cárdenas G, Ávila-Meléndez LA, Nava-Velázquez J, Villalpando1085 Barragán F, Estrada-Godoy F, Ochoa-Estrada S (2019) Geological heritage of the North 1086 Region of the State of Michoacan, Mexico. Geoheritage 11(3):1057-1065. 1087 https://doi.org/10.1007/s12371-019-00353-6

1088 Tavares GND, Boggiani PC, Leme JM, Trindade RI (2020) The inventory of the 1089 geological and paleontological sites in the area of the Aspirant Geopark Bodoquena1090 Pantanal in Brazil. Geoheritage 12, 28. https://doi.org/10.1007/s12371-020-00437-8

1091 Thomaz-Filho A, Cesero P, Mizusaki AM, Leão JG (2005) Hot spot volcanic tracks and 1092 their implication for South American plate motion, Campos basin (Rio de Janeiro state), 1093 Brazil. J S Am Earth Sci 18(3-4):383-289. https://doi.org/10.1016/j.jsames.2004.11.006

1094 Turcq B, Martin L, Flexor JM, Suguio K, Pierre C, Tasayco Ortega L (1999) Origin and 1095 evolution of the Quaternary coastal plain between Guaratiba and Cabo Frio, State of Rio 1096 de Janeiro, Brazil. In: Koopers B, Bidone ED, Abrãao JJ (eds) Environmental 1097 geochemistry of coastal lagoon systems of Rio de Janeiro, Brazil. Universidade Federal 1098 Fluminense, Niterói pp 25-46

1099 Wimbledon WAP, Smith-Meyer S (eds.) (2012) Geoheritage in Europe and its 1100 conservation. ProGEO, Oslo

1101 Zalán PV, Oliveira JAB (2005) Origem e evolução estrutural do Sistema de Riftes 1102 Cenozoicos do Sudeste do Brasil. Boletim de Geociências da Petrobras 13(2):269-300

1103 Zenkovitch VP (1959) On the genesis of cuspate spits along lagoon shores. J Geol 1104 67(3):269-277

1105 Zouros N (2007) Geomorphosite assessment and management in protected areas of 1106 Greece. Case study of the Lesvos Island - coastal geomorphosites. Geogr Helv 62(3):1691107 180. https://doi.org/10.5194/gh-62-169-2007 